\title{
Desafuero eclesiástico, desamortización y tolerancia de cultos: una aproximación comparativa a las reformas liberales mexicana y colombiana de mediados del siglo XIX
}

\author{
José David Cortés Guerrero \\ Universidad Nacional de Colombia \\ davidclio@hotmail.com
}

\begin{abstract}
Resumen $^{1}$
Este artículo muestra, de manera comparada, tres aspectos importantes de las reformas liberales de mediados del siglo XIX en México y la Nueva Granada: el desafuero eclesiástico, la desamortización y la tolerancia de cultos. Resalta la forma como ellos fueron abordados por los legisladores en cada uno de los países, indicando tanto diferencias como similitudes y haciendo énfasis en las posibles influencias de un caso en el otro. Se prefirió exponer, en primer lugar, en cada uno de los tres tópicos a tratar, el caso mexicano. En seguida, se hizo alusión a la Nueva Granada, entrando allí a determinar las similitudes y diferencias con México, de tal forma que el peso de la exposición recayera en lo acaecido allí.
\end{abstract}

Palabras clave: REFORMAS LIBERALES, IGLESIA, MÉXICO, NUEVA GRANADA, SIGLO XIX.

\begin{abstract}
This article explores from a comparative perspective three important aspects in the liberal reforms that took place in mid 19th century Mexico and New Granada. These aspects are loss of ecclesiatical rights, land disentailment, and religious tolerance. It highlights the manner in which these topics were engaged by legislators in each country, pointing towards differences and similarities, and emphasizing the possible influence of one case upon the other. For example, the discussion on religious tolerance in Mexico in 1857 had as a reference what was discussed and approved in New Granada in 1853, and land disentailment in the latter in 1861 reflects what had taken place years before in Mexico.
\end{abstract}

Key words: LIBERAL REFORMS, CHURCH, MEXICO, NUEVA GRANADA, $19^{\mathrm{TH}}$ CENTURY.

Agradezco a la doctora Alicia Hernández Chávez, profesora del Centro de Estudios Históricos de El Colegio de México y presidenta del Fideicomiso Historia de las Américas, los comentarios hechos a este texto. 
La década de 1850 fue bastante intensa en México y la Nueva Granada. En el primero, la caída de Santa Anna y la promulgación de una serie de medidas liberales, como las leyes Juárez y Lerdo, enfrentó a sectores liberales y conservadores, aliados estos últimos con la Iglesia católica, institución cuyos intereses se veían afectados por tales medidas ${ }^{2}$. También en la Nueva Granada un conjunto de medidas buscó separar la Iglesia católica del Estado, tratando de limitar el poder y la influencia de la primera en la sociedad. La separación era vista como necesaria en la medida que permitía delimitar el espacio de acción tanto del Estado como de la Iglesia, y le daba al Estado la posibilidad de fortalecerse pues reducía el poder social de la Iglesia. Esa separación también le permitía proyectar una modernización legal que equilibrara ante la ley a todos los sujetos, sin ningún tipo de privilegios. Es decir, la separación era necesaria para emprender un camino hacia la modernidad.

En 1856, en México se convocó a un congreso constituyente para que redactase una nueva Constitución, en la cual se incorporarían las mencionadas leyes Juárez y Lerdo y se trataría el tema, entre otros, de la libertad de conciencia y, por consiguiente, de la tolerancia de cultos. La Ley Juárez, firmada en 1855, sobre administración de justicia, y la Ley Lerdo, aprobada en 1856, sobre desamortización, fueron discutidas e incorporadas en la nueva Constitución, mientras que el Artículo 15 del proyecto de Constitución, que trataba sobre la libertad de conciencia, tras profuso debate, fue rechazado por la mayoría de los constituyentes ${ }^{3}$. Mientras tanto, en la Nueva Granada se eliminaron los fueros hacia 1851 y la desamortización se hizo efectiva diez años después. En cuanto a la libertad de cultos, fue incorporada en la Constitución de 1853. Debemos anotar, no obstante, que estos no fueron los únicos países de la región que implementaron reformas liberales en aquella época. Algunos historiadores piensan que la mitad del siglo XIX es un parteaguas en la historia contemporánea de América Latina, porque los liberales intentaron imponer, muchas veces por la fuerza, medidas secularizantes.

La constitución mexicana de 1857 y la leyes de Reforma que la complementan representan el documento político que ejemplifica esta voluntad de hacer regresar a la Iglesia católica a las sacristías y a la privacidad de las conciencias $[\ldots]^{4}$.

A pesar de que los casos mexicano y neogranadino no fueron únicos ni primigenios, sí tuvieron gran repercusión en la región, y en cada uno de estos dos países marcaron su historia durante el siglo XIX.

2 Para una contextualización de la época, entendida en medio de un proceso de más largo aliento, véase Alicia Hernández Chávez, México. Una breve historia. Del mundo indígena al siglo XX (México: Fondo de Cultura Económica, 2002).

3 Sobre el entorno liberal de las reformas, véase Lilia Díaz, “El liberalismo militante”, en Historia general de México (México: El Colegio de México, 1999).

4 Jean-Pierre Bastian, La mutación religiosa de América Latina (México: Fondo de Cultura Económica, 1997), 35. 
Aunque la Reforma mexicana es el ejemplo más conocido del funcionamiento del liberalismo a mediados del siglo XIX, los logros de los liberales colombianos durante el mismo período fueron muy similares -y en algunos casos superaron- a los de sus colegas mexicanos ${ }^{5}$.

Las reformas liberales neogranadinas comenzaron unos años antes que las mexicanas y no estuvieron antecedidas por una dictadura como la de Santa Anna. Se iniciaron en el primer gobierno liberal reconocido en el país, después de la creación de los dos partidos políticos tradicionales colombianos, el liberal y el conservador. En 1849, el liberal José Hilario López obtuvo una victoria electoral en el Congreso, que lo eligió como presidente del país. Por su parte, las reformas liberales mexicanas estuvieron mediadas por un conflicto de tres años conocido como la Guerra de Reforma, que radicalizó a los sectores liberales y conservadores enfrentados.

La existencia de casos como los de México y la Nueva Granada nos indica que a mediados del siglo XIX las fuerzas políticas ascendentes, de corte liberal, estaban buscando con gran fuerza romper las estructuras coloniales persistentes para poder así construir un Estado moderno, lo que obligaba a la secularización de la sociedad. Para ello era necesario terminar los privilegios de sectores como la Iglesia católica y el ejército y separar definitivamente las potestades. Los caminos que siguieron en cada uno de los países las llamadas reformas liberales fueron disímiles y dejan ver la confrontación entre los sectores políticos liberales y conservadores. Por ejemplo, y a la postre, las reformas en Colombia no lograron construir un proyecto político persistente y ya habían fracasado al comenzar la década de 1880. Entre tanto, en México persistieron y lograron proyectarse hasta el porfiriato y el siglo XX.

La coincidencia temporal, y la forma como en determinados momentos encontramos referencias a cada uno de los casos en el otro país, nos incitó a mirar cómo se presentaron, tanto en México como en la Nueva Granada, tres aspectos específicos: el desafuero eclesiástico, la desamortización y la tolerancia de cultos. Por ejemplo, cuando los constituyentes mexicanos discutieron en 1856 sobre la tolerancia de cultos hubo referencias explícitas a la forma como en la Nueva Granada se había avanzado en esa materia; así mismo, la desamortización en Colombia tomó puntos textuales de la que se había llevado a cabo años antes en México.

Como hipótesis de trabajo, aunque esta sea muy socorrida y utilizada con cierta regularidad, creemos que en los casos mexicano y neogranadino las medidas que afectaron los privilegios de sectores como la Iglesia católica, tales como el desafuero, la

5 David Bushnell y Nelly Macaulay, El nacimiento de los países latinoamericanos (Madrid: Nerea, 1989), 212. Sobre este tópico pueden verse, entre otros: Antonio Annino y François-Xavier Guerra, coords., Inventando la nación. Iberoamérica. Siglo XIX (México: Fondo de Cultura Económica, 2003) y Hans-Joachim König, En el camino hacia la nación (Bogotá: Banco de la República, 1993). 
desamortización y la separación Iglesia-Estado, entre otros, hacían parte de un proyecto liberal mucho más amplio que buscaba romper las estructuras coloniales persistentes y restarle poder a sectores tradicionalmente fuertes que de una u otra forma podían competir en fuerza e importancia con el proyecto de Estado que esos sectores liberales tenían planeado ejecutar. Por ello resulta difícil comprender aisladamente esas medidas, que han sido calificadas como anticlericales. Además, estaban a tono con lo que sucedía en otras partes del continente americano y con la evolución del pensamiento político europeo, inclinado por la modernidad y la formación del ciudadano. Esto puede observarse en las alusiones que se hacen al caso neogranadino en México y al mexicano en la Nueva Granada, mostrando la circulación de las ideas. Sin embargo, el planteamiento y la discusión de las reformas no fueron fáciles, presentaron muchos contratiempos y recibieron agrias críticas, lo que indica la persistente fuerza de sectores conservadores y de la misma Iglesia, que veían en peligro su modus vivendi, sus privilegios y statu quo. Esto explica los fuertes debates que suscitó el planteamiento de las reformas.

En cuanto a este artículo, para acercarnos a los tres tópicos atrás mencionados, desafuero, desamortización y tolerancia de cultos, se ha recurrido al recuento que de las discusiones en el congreso constituyente mexicano hizo Francisco Zarco, tratando de ser lo más minuciosos posible. Infortunadamente, los historiadores colombianos no contamos con una fuente como esta. Ninguno de los políticos contemporáneos se preocupó por seguir detalladamente las discusiones sobre temas tan trascendentales. Es por ello que hacer una reconstrucción del proceso implica el empleo de otras fuentes, esencialmente de la prensa periódica. Esto, obviamente, presenta límites, pues reduce la exposición al ámbito de las discusiones de los legisladores y políticos, pero también ofrece ventajas, pues nos deja conocer cómo unos y otros defendieron sus posiciones sobre el papel que debía jugar el Estado en sus relaciones con la Iglesia. Nos ayuda, entonces, a acercarnos a los ideales de quienes de una u otra forma comenzaron a delinear los proyectos de lo que debería ser el Estado en los dos casos tratados. No nos referiremos en detalle al contexto, que demandaría un espacio del que no disponemos aquí, pero la bibliografía referenciada permitirá al lector darse una idea de la forma como se desarrollaron los procesos históricos referenciados.

Se ha preferido exponer, en primer lugar, en cada uno de los tres tópicos a tratar, el caso mexicano. Inmediatamente se hace alusión a la Nueva Granada, entrando allí a determinar las similitudes y diferencias con México, de tal forma que el peso de la exposición recaiga en lo acaecido allí. Cuando se citan posiciones se explicita si corresponden a un constituyente en el pleno del Congreso, en el caso mexicano, o si hacen parte de la opinión pública, encabezada esencialmente por la jerarquía de la Iglesia.

\section{La Ley Juárez y el desafuero eclesiástico}

Uno de los puntos que discutió la constituyente de 1856 fue incluir en la Constitución la Ley Juárez en lo concerniente al desafuero eclesiástico y militar. La ley fue expedi- 
da el 23 de noviembre de 1855 y, además de lo referente a los fueros, tocaba aspectos sobre la administración de justicia de los tribunales de la nación, del distrito y de los territorios. Sin embargo, el asunto que causó polémica entre los constituyentes fue la eliminación de los fueros, teniendo en cuenta que algunos de ellos no consideraban pertinente incluir en la nueva carta la esencia de la ley. En este apartado del trabajo se verán los debates que se presentaron en la constituyente, mostrando las diversas tendencias existentes.

La primera posición asumida en la discusión de la ley en el pleno del Congreso fue la expuesta por la comisión de justicia de la constituyente, conformada por Ignacio Mariscal, Francisco García Anaya y Eulogio Barrera, que la revisó y que estipuló que el principio de eliminación de los fueros era un gran avance en materia de justicia:

El principio consignado en la ley, es un gran paso hacia la igualdad social, puesto que la abolición del fuero civil en cuanto a los eclesiásticos, y del civil y criminal por delitos comunes en cuanto a los militares, es la satisfacción de dos necesidades que reclamaban, no solo la consecuencia con los principios democráticos, sino las circunstancias particulares de nuestra sociedad; a la que ha servido de constante rémora para sus adelantos, la preponderancia de las citadas clases ${ }^{6}$.

Así, la comisión aprobó la propuesta el 12 de abril de 1856 para ser presentada al pleno del Congreso. Una vez hecha la propuesta, aparecen varios puntos de vista sobre la citada ley y su inclusión en la Constitución. Barrera, integrante de la comisión de justicia, recalcó, siguiendo el lineamiento de sus compañeros de comisión, que la ley "debía sancionarse por el congreso como la gran conquista de la revolución, deseada y anhelada por el pueblo"7. Otro de los integrantes de la comisión, Mariscal, era de pensamiento similar. Para él ese era el tiempo oportuno para tratar la cuestión de los fueros:

La revisión es prudente y política, porque los fueros sirvieron de pretexto a la reacción, porque si la asamblea quiere afirmar el orden público y consolidar la libertad, está en el deber de hacer pedazos la bandera de la rebelión y de frustrar hasta las últimas esperanzas de los reaccionarios $[\ldots]^{8}$.

Mariscal también advertía que en la ley solo había tres puntos de importancia política: la supresión de fueros, la organización de la Suprema Corte y de la Corte Marcial y la creación del Tribunal Superior de Distrito. Estas declaraciones de Barrera y Mariscal

${ }_{6} \quad$ Francisco Zarco, Historia del Congreso Extraordinario Constituyente de 1856 y 1857 (México: Congreso de la Unión, 1990), 1: 137-138.

7 Ibídem, 166.

$8 \quad$ Ibídem, 169. 
pueden ser calificadas como moderadas, si vemos tanto las posturas que rechazaban la medida como aquellas que la consideraban muy blanda para las condiciones del país y para el proyecto liberal que se deseaba construir.

La propuesta de discutir el punto fue rechazada por unos pocos constituyentes. El más radical de ellos fue Marcelino Castañeda, representante de Durango, quien advirtió que aún no era tiempo para involucrarse en ese debate. Comenzando las reuniones del congreso constituyente, propuso que fuese restablecida la Constitución de 1824, pues, según afirmaba, la Ley Juárez era muy precipitada para el país, y, de restablecerse la Constitución de 1824, los fueros seguirían vigentes. Esto debía ser así hasta que se expidiese una nueva Constitución. Teniendo en cuenta esta apreciación, el Congreso, en su debido momento, debía revisar la ley y hacerle las modificaciones que considerase pertinentes ${ }^{9}$. Castañeda estaba de acuerdo en que los fueros debían ser abolidos, pero más adelante, sin proceder con precipitación; decía:

[...] la cuestión de fueros es gravísima [...] pues afecta a más de la mitad de la nación; no hay que anticipar la resolución del congreso, que debe venir después de una discusión detenida y concienzuda de los fueros ${ }^{10}$.

Se preguntaba, además: “¿quiere la nación que se conquisten principios a costa de torrentes de sangre?”"11, haciendo alusión al triunfo del gobierno sobre la rebelión proclerical de Puebla. Propuso, en conclusión, no revisar el asunto o posponerlo. Que afirmara que esa cuestión afectaba a más de la mitad de la nación deja ver la idea que los sectores conservadores tenían al respecto: la pérdida de privilegios ante la ley con el desafuero rompía las estructuras tradicionales de desigualdad jurídica y ponía a militares y eclesiásticos al nivel de ciudadanos sumisos a la ley civil. Pero también indica que esos sectores eran muy fuertes y harían lo posible para impedir la aprobación y, si esto no fuese posible, el funcionamiento del desafuero.

Otros legisladores, como Rafael Jaquez, representante del estado de Guerrero, solicitaron que la discusión del punto se hiciera una vez estuviese redactada la Constitución, por lo que sería necesario aplazar el debate. Con ello se lograría, además, evitar

9 Ibídem, 167-168. La Constitución de 1824 mostraba el respaldo irrestricto a la religión católica. Esto puede verse en el artículo tercero: "La religión de la nación mexicana es y será perpetuamente la católica, apostólica, romana. La nación la protege de leyes sabias y justas, y prohíbe el ejercicio de cualquier otra”. Las Constituciones de México, 1814-1989 (México: H. Congreso de la Unión, Comité de Asuntos Editoriales, 1989), 75.

10 Zarco, Historia, 178. Sobre el papel preponderante que tenían tanto el clero como los militares desde la Independencia, véase: Cristina Gómez Álvarez, "Mitra y sable se unen para sellar la independencia”, en Relaciones Estado-Iglesia. Encuentros y desencuentros, comp. Patricia Galeana (México: Archivo General de la Nación, 1999).

11 Zarco, Historia, 178. Sobre la sublevación de Puebla, véase: Jan Bazant, "La Iglesia, el Estado y la sublevación conservadora de Puebla en 1856”, Historia Mexicana (México), 35, núm.1 (julio-septiembre, 1985). 
la predisposición del Congreso en un asunto que parecía delicado ${ }^{12}$. La diferencia con la posición de Castañeda radicaba, esencialmente, en que estos legisladores que pedían que se postergase el debate no iban a tomar una actitud radical en este tema ni en otros que más adelante trató el Congreso.

La solicitud de suspensión o aplazamiento no fue bien recibida por la mayoría de los constituyentes. José Antonio Gamboa, representante del estado de Oaxaca, incitó a que se debatiera el asunto de los fueros, "que todo lo demás era secundario y el gobierno podía variarlo conforme a lo que resultara de la experiencia"13. Esa intervención hizo que no se suspendiera la discusión. En la continuación del debate pueden verse varias tendencias: la de los que estaban de acuerdo con la inclusión de un artículo en la Constitución que eliminara los fueros, y la de quienes creían que la propuesta se quedaba corta, pues no profundizaría realmente en el problema de la supresión de los fueros.

En la primera línea aparecen posiciones como la de Juan Antonio de la Fuente, quien advirtió que la supresión fue necesaria porque "los fueros se convirtieron en poderosísimos auxiliares de la opresión y de la tiranía, y era preciso destruirlos para redimir a este pueblo"14. Igual sucedió con el planteamiento de Vicente López, representante del estado de Guanajuato, quien advirtió que "el clero no necesita privilegios que desequilibran la sociedad y tienden a que el sacerdocio, apartándose de su carácter sagrado, se sobreponga a las demás clases”15. Es interesante notar que quienes defendieron la supresión de los fueros lo hacían con el ánimo de igualar a todos los hombres ante la ley, evitando los privilegios y los abusos que podían generarse con los desequilibrios legales. Pero también lo hacían con el ánimo de terminar esos desequilibrios existentes desde el mundo colonial, lo cual refuerza nuestra hipótesis de que estas medidas buscaban romper las viejas estructuras coloniales aún persistentes, a pesar de que la Independencia había consumado la ruptura con España hacía más de treinta años.

En la segunda línea, la de aquellos a quienes podemos llamar radicales, se encontraban los legisladores Antonio Escudero y Antonio Aguado. El primero estaba en contra del dictamen presentado por la comisión de justicia, esencialmente porque veía que ella se había equivocado al no suprimir el fuero eclesiástico en materia criminal. Esto permitiría a la reacción seguir teniendo armas contra quienes desearan el progreso para la sociedad ${ }^{16}$. Por su parte, el señor Aguado no creía que la Ley Juárez conquistase el principio de libertad que tanto proclamaba:

\footnotetext{
12 Zarco, Historia, 168.

13 Ibídem, 168.

14 Ibídem, 175.

15 Ibídem, 177.

16 Ibídem, 171.
} 
La ley al conceder el fuero criminal a los eclesiásticos les ha dado más de lo que antes tenían, y así no se trata de la igualdad, sino de un principio más alto, más importante para la soberanía de la nación. Cuando se ha querido sostener que los fueros del clero son de origen divino, el gobierno de México los da en unas materias, los quita en otras, combate con hechos tan erradas doctrinas, y así defiende las atribuciones del poder temporal, la independencia del sumo imperante para legislar en estos puntos y hacer el bien de la sociedad, siendo esta la conquista de la ley y el medio de llegar a hacer efectiva la verdadera igualdad. Esto es lo que merece aprobación, porque sanciona y defiende la soberanía nacional: esto es lo que debe aprobarse para salvar todo inconveniente y dar más fuerza al poder temporal ${ }^{17}$.

Luego de una discusión muy corta y de escuchar las razones expuestas, se pasó a la votación en el pleno del Congreso. El resultado fue de 82 votos contra uno, el de Marcelino Castañeda. En su historia del Congreso, Zarco concluye esta parte con las siguientes palabras, en las cuales es clara la toma de posición: “¡No más fueros! no más privilegios! no más escenciones! igualdad para todos los ciudadanos! soberanía perfecta del poder temporal! justicia para todos!”18. Con estas declaraciones se mostraba el claro interés por quebrar los privilegios y las desigualdades que ante la ley tenían algunos sectores. Sin embargo, y tras una lectura inicial del proceso, parece que los liberales radicales tenían razón al afirmar que poco se había avanzado con esta ley, pues las corporaciones a las que se les quería limitar sus privilegios resultaron fortalecidas en la medida que el desafuero no fue profundo, lo cual debilitaba, de acuerdo con esa postura radical, la soberanía del Estado en materia jurídica, pues seguían persistiendo privilegios ante la ley ${ }^{19}$.

17 Ibídem, 177. La Ley Juárez en su Artículo 42, decía así: “Se suprimen los tribunales especiales, con excepción de los eclesiásticos y militares. Los tribunales eclesiásticos cesarán de conocer en los negocios civiles, y continuarán conociendo de los delitos comunes de individuos de su fuero, mientras se expide una ley que arregle ese punto [...] Las disposiciones que comprende este artículo, son generales para toda la república, y los Estados no podrán variarlas ni modificarlas”. Ibídem, 148. Este artículo fue reelaborado por la Comisión de Justicia del Congreso Constituyente, que redactó el proyecto de artículo 13 en la Constitución de 1857, el cual fue aprobado, como vimos en el interior del texto, por el pleno del Congreso.

18 Ibídem, 182. En la Constitución de 1857 el artículo relativo a fueros es el número 13: “En la República Mexicana nadie puede ser juzgado por leyes privativas, ni por tribunales especiales. Ninguna persona o corporación puede tener fueros, ni gozar emolumentos que no sean compensación de un servicio público, y estén fijados por la ley. Subsiste el fuero de guerra solamente por los delitos y faltas que tengan exacta conexión con la disciplina militar. La ley fijará con toda claridad los casos de excepción”. Las constituciones, 160. Este artículo alude a la Ley Juárez. Para conocer el texto completo de la citada ley, véase: Zarco, Historia, 140-157.

19 Jean-Pierre Bastian, Los disidentes: sociedades protestantes y revolución en México, 1872-1911 (México: Fondo de Cultura Económica; El Colegio de México, 1989), 28. 
Las diferentes posiciones sobre los fueros dejan ver la necesidad de defender estamentos de la sociedad que jugaron papel importante, ya fuese en la Colonia o en la reciente Independencia. Los que los defendían mostraban con ello la imposibilidad del principio liberal de la igualdad ante la ley. Sus oponentes, por el contrario, creían en ese principio en pos, siempre, de la formación del ciudadano.

\section{El desafuero en la Nueva Granada}

Eliminar el fuero eclesiástico fue uno de los propósitos de la administración de José Hilario López (1849-1853). Para él, si el clero continuaba con el fuero, tendría el pretexto para desobedecer las leyes civiles y, en última instancia, la Constitución, generando disputas jurídicas con el Estado y socavando sus competencias y su fuerza para regular la vida de los ciudadanos. Por ello decidió acabar con el fuero por medio de la Ley de 14 de mayo de 1851. El desafuero reclamaba que desde los arzobispos hasta el clero secular o regular estuviesen a disposición de las autoridades civiles, en caso de violar el código penal vigente. Desde la Corte Suprema de Justicia hasta los tribunales de distrito y los jueces de circuito serían los encargados de juzgar en primera y segunda instancias a los clérigos infractores.

La ley determinaba que quedaba extinguido todo fuero o privilegio eclesiástico, encargando a la Corte Suprema de Justicia el conocimiento de todas las causas criminales que se siguiesen, por mal desempeño de sus funciones o por delitos comunes, contra los arzobispos y obispos. La misma corte se encargaría de conocer, en segunda instancia, los pleitos promovidos contra miembros de ambos cleros. Los tribunales de distrito se encargarían, en primera y segunda instancia, de las causas criminales contra provisores, vicarios generales y capitulares. Por su parte, los jueces de circuito o parroquiales se encargarían, en primera instancia, de las causas civiles contra miembros de los dos cleros. Debe anotarse que las causas seguidas contra individuos del clero por el mal desempeño de sus funciones correspondían también a los jueces del circuito, en primera instancia, y a los tribunales de distrito, en segunda instancia ${ }^{20}$. En este sentido, la medida era mucho más fuerte y profunda que en México, ya que los tribunales civiles se ocuparían de las causas criminales de los clérigos, aspecto este que era solicitado para su país por los constituyentes Escudero y Aguado, tal como se vio atrás.

Una vez conocido el decreto, la jerarquía de la Iglesia católica, afectada por tal determinación, y afirmando que con ella se rompía la unidad y la disciplina de la Iglesia, protestó vehementemente, mostrando que se vulneraba un derecho de origen divino, que había sido acatado y respetado a lo largo de los siglos y reafirmado

20 Juan Pablo Restrepo, La Iglesia y el Estado en Colombia (Londres, 1885; reimpresión, Bogotá: Banco Popular, 1985), 1: 437-438. 
por autoridades eclesiásticas y terrenales ${ }^{21}$. El arzobispo de Bogotá, Manuel José Mosquera, rechazó la ley por considerarla contraria a la autoridad interna de la institución eclesiástica. Mosquera afirmó:
[...] en mi carácter de Metropolitano de esta Provincia, y a nombre de mi Iglesia, reclamo ante los poderes nacionales, la libertad e inmunidad de la Igle- sia en el ejercicio de su autoridad divina en las causas criminales que, por mal desempeño en el ejercicio de sus funciones, puedan tener lugar contra los indi- viduos de la jerarquía católica en uno y otro clero. Jamás la Iglesia ha consen- tido en que las causas eclesiásticas sean juzgadas por la autoridad civil²2.

Es notorio que la discusión se encaminó al enfrentamiento y la competencia de las potestades civil y eclesiástica para regular sus actividades sin inmiscuirse en los asuntos relativos a la otra, y que abordó las competencias legales del Estado. También estaba de fondo la necesidad de construir la imagen de ciudadanos iguales ante la ley. Otro asunto era que Mosquera, como en el caso mexicano, aducía que la autoridad de la Iglesia tenía origen divino y, por lo tanto, los hombres no podían inmiscuirse en ella para resolver sus asuntos. El mismo arzobispo Mosquera, en comunicación del 19 de marzo de 1851, dos meses antes de la aprobación de la ley, alegó la inconveniencia de la

21 Ejemplo de esta actitud de defensa del fuero eclesiástico como un derecho divino e imperecedero es la carta escrita por el obispo de Popayán, suroccidente de la Nueva Granada, al presidente de la República, José Hilario López, el 11 de junio de 1850. “Entenderse la ley del desafuero eclesiástico a privar a los juzgados y tribunales de su especie, de la intervención y conocimiento de aquellas causas, es haber desconocido su autoridad, y haber dado un golpe mortal a la Iglesia, haber desconocido su autoridad, haber propuesto imprescriptibles derechos a los nuevamente creados por la ley de aquella naturaleza, que está en abierta pugna con los cánones de muchos concilios, y en notoria oposiciones del de Trento, cuyas determinaciones han sido consideradas, acatadas y respetadas en todo tiempo y en cualquier circunstancia. La ley del fuero eclesiástico en toda época se ha tenido como necesaria para mantener la independencia de la Iglesia, y para hacer respetar sus sagrados e inviolables derechos [...] Si pues tal atribución se ha dado a los tribunales, juzgando civiles, por ella Ciudadano Presidente, se ha despojado a la Iglesia de su poder espiritual, se ha visto con indiferencia la fuente de donde le vienen aquellos derechos, que lo es el derecho divino. Con dicha atribución dada a los juzgados seculares, se confunde el poder temporal con el espiritual, quedando este en todo, sometido el primero; por manera que habrá embarazos para la administración, los que crecerán a medida que crezcan y se desenvuelvan los partidos políticos a que por desgracia se ven siempre reducidos los pueblos de un Estado [...] Meditad Ciudadano Presidente, sobre los males que acarreará a la Iglesia aquella ley, y en particular la disposición de la que me he ocupado, y hacedlos palpables a la próxima legislatura a fin que se ponga remedio a tan funesto y luctuoso porvenir [...] si es que no se ha conseguido aun su derogatoria”. El Catolicismo (Bogotá), núm. 41, 1 de julio 1850, p. 341.

22 Restrepo, La iglesia, 1: 441. El enfrentamiento entre las potestades, que se observaba y apuntaba a la separación total, fue mostrado históricamente por el arzobispo bogotano, para quien la injerencia de lo político en lo eclesiástico no era aceptado desde los orígenes de la Iglesia. "Cuando Constancio se propuso dar leyes sobre cosas espirituales a los Obispos, Osio de Córdoba, el oráculo de los concilios, le dijo con santa libertad: ‘Has visto, oh Emperador, que Constantino se haya entrometido en los juicios eclesiásticos? No te mezcles, pues, tú en las cosas de la Iglesia, ni nos des preceptos, sino más bien apréndelos de nosotros. A ti se te ha dado el Imperio, a nosotros se nos dio la Iglesia'”. Ibídem. 
injerencia de la autoridad civil en la autoridad eclesiástica, pues, de ser así, los “principios dogmáticos, de los cuales ni la misma Iglesia puede prescindir”, se pondrían en peligro $^{23}$

El 9 de junio de 1851, el obispo de Calidonia, auxiliar del metropolitano de Bogotá, escribió desde Puente Nacional, departamento de Santander, una carta al presidente de la República, José Hilario López. Afirmaba que por dicha ley se le quitaba

[...] la libertad e inmunidad a la Iglesia en el ejercicio de la autoridad divina que recibió de Jesucristo, abrogándose [sic] la potestad civil el conocimiento de las causas criminales de los individuos de la jerarquía eclesiástica, que puedan ocurrir por el mal desempeño en el ejercicio de sus funciones [...],

siendo ello muy perjudicial para el clero y poniéndolo, en su caso personal, en el "penoso conflicto de tener que elegir entre un deber sagrado de derecho divino, y uno de ley que lo contradice" ${ }^{24}$. Con esta afirmación salía a la luz el meollo de la discusión: ante quién debía rendir cuentas legales un clérigo: ¿ante Dios o ante los hombres? Era, en esencia, el mismo problema presente en México. De igual forma, para el mencionado obispo, era deplorable que en menos de medio siglo de la República ya se presentase este tipo de funestas contrariedades, máxime cuando el país aún era muy inestable políticamente. Esto, en últimas, significaba que el desafuero contribuiría a esa inestabilidad y posiblemente conduciría a la confrontación y, por ende, a la guerra civil.

En la misma tónica, también se comunicó al presidente del país, desde la ciudad de Pasto, el 24 de junio de 1851, José Elías Puyana, obispo de Caradro y auxiliar del diocesano de Popayán. La queja iba en la misma dirección de la anterior: mostrar la inconveniencia de la ley de desafuero eclesiástico:

Es mi deber como Obispo católico reclamar su reforma [la de la ley] [...] porque ella priva la Iglesia de su autoridad espiritual en las causas criminales que por mal desempeño en ejercicio de sus funciones se sigan a los Obispos, Provisores, Vicarios generales, Capitulares, y a los individuos de uno y otro clero, de la cual he citado en posesión por una serie continuada de siglos [...] $]^{25}$.

La cuestión era clara. La jerarquía de la Iglesia defendía su privilegio de juzgar a los integrantes de ella que cayesen en desgracia por desacato o violación de sus normas internas. El poder civil deseaba romper ese privilegio para que todos lo miembros del

23 Ibídem, 1: 440.

24 El Catolicismo (Bogotá), núm. 40, 15 de junio 1851, p. 333.

25 Ibídem, núm. 43, 24 de enero 1852, p. 359. 
clero se comportasen como ciudadanos sin privilegios, con derechos y deberes. Era, en esencia, la aplicación del principio liberal de la igualdad de todos los hombres ante la ley.

El historiador decimonónico colombiano, Juan Pablo Restrepo, al criticar la ley, indicó que ella reducía las funciones de los clérigos a asuntos netamente espirituales. Sin embargo, esa era una de las esencias de las reformas liberales: someter materialmente a la Iglesia, para quitarle el poder temporal que tenía sobre la población y reducir sus actividades a asuntos del orden privado. Por su parte, el presidente López, en comunicación de 1853 al Congreso, insistió en la necesidad de separar las potestades, que era, en última instancia, lo que se pretendía con las medidas que se estaban tomando:

Desde el momento -se quejaba López- en que el Episcopado granadino no encontró en las leyes de la República la utilidad que buscaba en la confusa mezcla de lo espiritual y lo material, protestó contra esas leyes, las resistió abiertamente, y aún dio lugar con su conducta a que las pasiones políticas se lanzaran en la rebelión [...] [pues] a fuerza de abusar del nombre de esa Religión y de mezclarlo en los festines de sangre y de persecución, los granadinos oyen con desconfianza, si no fuera con desprecio, las palabras de esos falsos apóstoles que predican la guerra, en vez de la paz; que excitan los odios, en vez del amor; que exhortan a la desobediencia, en vez de aconsejar el respeto a la autoridad constituida ${ }^{26}$.

La discusión se encaminó a la separación de las potestades y dejó ver los ánimos caldeados por las partes más antagónicas defensoras de sus derechos y privilegios. Igual sucedería con la libertad de cultos, aprobada en la Constitución de 1853.

\section{La Ley Lerdo y la desamortización}

El 28 de junio de 1856, un grupo de constituyentes pidió que se ratificara y aprobara en todas sus partes el decreto expedido por el gobierno tres días atrás, que trataba sobre desamortización de fincas rústicas y urbanas de las corporaciones civiles y religiosas de la República ${ }^{27}$. Cabe anotar que antes de la desamortización de 1856 se habían propuesto medidas similares. En 1831, Valentín Gómez Farías, funcionario del gobierno de Zacatecas, convocó un premio sobre el mejor trabajo sobre la temática de los bienes eclesiásticos. El ganador fue el ex sacerdote José María Luis Mora con el

26 Restrepo, La iglesia, 1: 439, 482.

27 Sobre la historia del proyecto de desamortización elaborado por Miguel Lerdo de Tejada a partir del proyecto de Haro y Tamariz, véase: Jan Bazant, Los bienes de la Iglesia en México (1856-1875): aspectos económicos y sociales de la Revolución liberal, 2 ed. (México: El Colegio de México, 1977), 56-70. Puede consultarse la también clásica obra de Robert Knowlton, Church Property and the Mexican Reform, 1856-1910 (DeKalb: Northern Illinois University Press, 1976). Para Knowlton, la Ley Lerdo fue el segundo mayor impacto de la Reforma (véase p. 24). 
texto "Disertación sobre la naturaleza y aplicación de las rentas y bienes eclesiásticos”. Esta obra

[...] puede considerarse como punto de partida del anticlericalismo decimonónico en México. Por vez primera, Mora expuso un argumento razonable y bien fundado acerca del derecho legal del Estado a intervenir en la propiedad amortizada, además de regularla, propiedad que daba sustancia material al poder corporativo de la Iglesia ${ }^{28}$.

En ese texto Mora demostró el carácter temporal de los bienes de la Iglesia, afirmando que por ese hecho estos no estaban alejados de la intervención del poder civil. Para Mora, la Iglesia podía ser vista desde dos enfoques:

[...] o como cuerpo místico, o como asociación política: bajo el primer aspecto, es la obra de Jesucristo, es eterna e indefectible, y enteramente independiente de la potestad temporal: bajo el segundo, es la obra de los gobiernos civiles, puede ser alterada y modificada, y aún pueden ser abolidos los privilegios que debe al orden social, como los de cualquiera otra comunidad política ${ }^{29}$.

El ex sacerdote deseaba probar que la Iglesia, como institución, pertenecía al segundo grupo, y que si bien no podía negársele el derecho a poseer bienes, debía sujetarse a la autoridad civil.

En 1833, las leyes que más impacto tuvieron fueron las que derogaban la coacción civil para el pago de diezmos, del 27 de octubre, y el cumplimiento de los votos monásticos, del 6 de noviembre. Estas leyes hicieron que Gómez Farías dejara la vicepresidencia, aunque ellas permanecieron, pues Santa Anna, el titular de la presidencia, no las derogó. Según Hale,

El ataque liberal a la propiedad eclesiástica se llevó a cabo de acuerdo con por lo menos tres principios. Uno, [...] era utilitarista y económico. El capital amortizado debía ponerse en libre circulación por parte de los individuos para propiciar el progreso económico. Otro, [...] era político y legal: el privilegio corporativo y el poder de la Iglesia debían eliminarse en favor de un régimen de derechos iguales y uniformidad administrativa dentro del Estado. El tercero era fiscal: la perpetua crisis financiera de la nueva república solo podía resolverse utilizando los bienes desamortizados de la Iglesia para poner las bases de un crédito público ${ }^{30}$.

28 Charles Hale, El liberalismo mexicano en la época de Mora, 1821-1853 (México: Siglo XXI, 1987), 136, citado en Lisette Griselda Rivera Reynaldos Desamortización y nacionalización de bienes civiles y eclesiásticos en Morelia, 1856-1876 (Morelia: Universidad Michoacana de San Nicolás de Hidalgo, 1996), 34.

29 José María Luis Mora, “Disertación sobre la naturaleza y aplicación de las rentas, y bienes eclesiásticos y sobre la autoridad a que se hallan sujetos en cuanto a su creación, aumento, subsistencia o supresión”, facsímil, México, 1957, citado en Rivera Reynaldos, Desamortización, 36.

30 Hale, El liberalismo, 138, citado en Rivera, Desamortización, 39. 
Anotamos que el argumento más utilizado fue el tercero. Lo propuesto por Gómez Farías, en cuanto afectar los bienes eclesiásticos, no pudo concretarse, pues provocó la reacción del clero y de los sectores conservadores. El ejército, en su mayoría, se sublevó para defender esos privilegios, con el grito "religión y fueros".

En 1847, también se buscó la desamortización de los bienes eclesiásticos con un proyecto encabezado por Antonio Haro y Tamariz. La ley fue expedida el 11 de enero de 1847 y buscaba que el gobierno obtuviese 15 millones de pesos subastando públicamente los bienes de manos muertas, con excepción de hospitales, hospicios, casas de beneficencia, colegios, capellanías y objetos de culto. La venta cubriría los gastos de la guerra contra Estados Unidos. El clero se opuso. En marzo, Santa Anna, que había regresado de la campaña militar, abolió la ley, al tiempo que solicitó de la Iglesia un préstamo por un millón de pesos.

Volviendo a 1856, el constituyente y cronista Francisco Zarco, en nombre de los proponentes, no ahorró elogios para la medida. Los motivos para proponer la desamortización eran claros:

[...] económica y progresista, [...] realizaba la gran reforma de dividir la propiedad territorial, de desamortizar bienes que estancados son muy poco productivos, de proporcionar grandes entradas al erario, y de facilitar la reforma al sistema tributario [...] Todas estas medidas se conquistan de una manera prudente, sin escándalo, sin precipitación, y sin dejar lugar a motivos fundados de resistencia, pues la ley no envuelve ni el despojo ni la expropiación [...] concilia de una manera admirable los intereses del pueblo, los del erario, y los del clero, que queda asegurado en la percepción de sus rentas, sin tener que hacer los gastos de conservación de sus fincas [...] y que así queda también asegurada la conservación del culto, sin que los enemigos de la reforma tengan el menor pretexto para extraviar la opinión pública ${ }^{31}$.

Para el mismo Zarco, aunque la medida era buena, no estaba exenta de ser atacada ni de encontrar dificultades para su aprobación. Según él, los conservadores desearían torpedearla por considerarla violenta, y algunos liberales pretenderían una medida más anticlerical:

A los primeros, les contestará la opinión pública, y la prosperidad y mejora de todo el país; a los segundos es preciso hacerles notar, que es una gran cosa conquistar el principio de la desamortización como base de otras reformas [... $]^{32}$.

Según Zarco, las medidas violentas solo servirían para fomentar la guerra civil. Es diciente de lo delicado de los asuntos que se discutían que, en temas como estos -en

21 Zarco, Historia, 598-600.

32 Ibídem, 601. 
los que pasaba algo similar a lo ocurrido con la libertad de cultos y la supresión de los fueros-, estuviese siempre presente el temor a la guerra civil. Zarco también afirmaba que era mejor que los bienes quedasen en una multitud de pequeños propietarios y no en poder del gobierno ${ }^{33}$. A pesar de ello, el constituyente Espiridión Moreno creía que la medida era tímida e indicaba miedo por parte del gobierno: "El clero asegura sus capitales, queda como censualista y puede maquinar contra la libertad. La ley, pues, peca por defecto" 34 . Al final de la discusión, que solo empleó el 28 de junio de 1856, el artículo número 27 de la Constitución fue aprobado en el pleno del Congreso por 78 votos contra 15. Redactado por la comisión de Hacienda, resumía la esencia de la Ley Lerdo y rezaba así:

\begin{abstract}
Ninguna corporación civil o eclesiástica, cualquiera que sea su carácter, denominación u objeto, tendrá capacidad legal para adquirir en propiedad o administrar por sí bienes raíces, con la única excepción de los edificios destinados inmediata y directamente al servicio u objeto de la institución ${ }^{35}$.
\end{abstract}

En el ámbito de la opinión pública y de la administración del país, tanto la aprobación de la Ley Lerdo como su inclusión en la Constitución de 1857 generaron posiciones encontradas. El gobierno de Ignacio Comonfort consideraba este hecho como un adelanto para el país: por ejemplo, Manuel Doblado, consejero del presidente, advirtió sobre la importancia de la ley:

33 Ibídem, 609.

34 Ibídem, 611. Críticos contemporáneos a la medida no consideran que la Ley Lerdo haya sido muy radical. Por ejemplo, Manuel Payno la calificó como una medida para consolidar la paz entre la Iglesia y el Estado. "As Manuel Payno put it some years later, the Lerdo Law, like all early Reform measures, was a compromise designed to 'consolidate peace between Church an State'”. Richard Sinkin, The Mexican Reform, 1855-1876. A study in Liberal Nation-Building (Austin: The University of Texas at Austin, 1979), 125.

35 Las Constituciones, 161. Sobre la Ley Lerdo, estos son sus principales artículos, que fueron sintetizados en el artículo 27 de la Constitución de 1857: “Art. $1^{\circ}$ Todas las fincas rústicas y urbanas que hoy tienen o administran como propietarios las corporaciones civiles o eclesiásticas de la república, se adjudicarán en propiedad a los que las tienen arrendadas, por el valor correspondiente a la renta que en la actualidad pagan, calculada como rédito al $6 \%$ anual; Art. $3^{\circ}$ Bajo el nombre de corporaciones se comprenden todas las comunidades religiosas de ambos sexos, cofradías y archicofradías, congregaciones, hermandades, parroquias, ayuntamientos, colegios, y en general todo establecimiento o fundación que tenga el carácter de duración perpetua o indefinida [...]; Art. $8^{\circ}$ Solo se exceptúan de la enajenación que queda prevenida, los edificios destinados inmediata y directamente al servicio u objeto del instituto de las corporaciones, aunque se arriende alguna parte no separada de ellos, como los conventos, palacios episcopales y municipales, colegios, hospitales, hospicios, mercados, casas de corrección y de beneficencia. Como parte de cada uno de dichos edificios, podrá comprenderse en esta excepción una casa que esté unida a ellos y la habiten por razón de oficio los que sirven al objeto de la institución, como las casas de los párrocos y de los capellanes de religiosas. De las propiedades pertenecientes a los ayuntamientos se exceptuarán también los edificios, ejidos y terrenos destinados exclusivamente al servicio público de las poblaciones a que pertenezcan”. Zarco, Historia, 597-598. Toda la Ley Lerdo aparece en el citado texto de Zarco, pp. 597-603. 
La Ley Lerdo regirá en México como aquella que tiempo después destruyó la coacción civil para el pago de diezmos. Estas leyes que son la expresión de la necesidad de un pueblo, son invulnerables ${ }^{36}$.

El mismo gobierno tuvo que defender la mencionada ley ante las críticas de que fue objeto por parte, esencialmente, de la jerarquía eclesiástica, que veía en ella una usurpación de la propiedad. Ante tal situación, el ministro Ezequiel Montes se dirigió al arzobispo de México, De la Garza, en los siguientes términos:

La ley [Lerdo] de que me ocupo deja a las corporaciones en posesión de todas sus rentas aseguradas con la hipoteca de las fincas que se rematen o adjudiquen; les reserva además la facultad de exigir a su satisfacción, fiadores de los réditos [...] Al dictar el presidente la referida ley, tuvo presente la miserable y precaria situación en que se halla reducida la mayoría del pueblo mexicano, estancada en su mayor parte la riqueza territorial y en consecuencia abandonada la agricultura, fuente abundante de riqueza en nuestro país ${ }^{37}$.

Por su parte, el obispo de Morelia, Clemente de Jesús Munguía, opinaba así sobre la venta de los bienes eclesiásticos:

Ninguno de los obispos ha pretendido jamás que la propiedad eclesiástica sea invendible. Es enajenable y de hecho se enajena cuando la utilidad y necesidad de la Iglesia calificada por su autoridad canóniga (sic) así lo exigen. Lo que decimos es que no se pueden vender contra la voluntad de la Iglesia, y esto no está desmentido, no está contradicho ni directa ni indirectamente por el citado texto de los Hechos Apostólicos ${ }^{38}$.

A pesar de las críticas recibidas, la Ley Lerdo, al parecer, cumplió con su cometido. El historiador Silvestre Villegas la calificó como "la medida más revolucionaria de todo el régimen”. Quienes más se vieron beneficiados fueron los que tenían dinero para adquirir los bienes: muchos liberales, conservadores y extranjeros. La mayoría eran mexicanos, por lo que se cree que "el régimen liberal logró interesar a la nación mexicana en las reformas y que Lerdo tuvo razón en impugnar la idea de que la ley solo sirvió para enriquecer a unos cuantos individuos”39. Esto en alusión a que la ley solo benefició a unos cuantos que lograron acaparar la tierra en venta. En Colombia pasó algo similar en

36 Manuel Doblado, "Memoria leída en la inauguración del H. Congreso del Estado el día 31 de julio de 1857”, 8. Archivo Manuel Doblado, Universidad de Guanajuato. Citado por Silvestre Villegas Revueltas, El liberalismo moderado en México, 1852-1864 (México: UNAM, 1997), 145.

37 “Contestaciones entre el arzobispo Lázaro De la Garza y el ministro Ezequiel Montes”, 6, Ibídem, 138.

38 Clemente de Jesús Munguía, En defensa de la soberanía, derechos y libertades de la Iglesia, 2 ed. (1857; reimpresión, México: Editorial Tradición, 1973), 16.

39 Villegas, El liberalismo, 131-133. 
cuanto a la explicación, pero la falta de estudios no permite decir con certeza si en efecto hubo un acaparamiento de la propiedad por parte de unos cuantos individuos.

\section{La desamortización en Colombia}

En cuanto a las tensas relaciones entre el Estado y la Iglesia católica en Colombia, el tema de la desamortización ha sido, tal vez, el que más espacio ha ocupado en la producción historiográfica ${ }^{40}$. Sin embargo, la mayor parte de esos estudios se han limitado al aspecto económico de la medida, dejando de lado el impacto en las mentalidades políticas de los sectores afectados, así como de aquellos que vieron y opinaron sobre la decisión de Mosquera.

La medida de desamortización fue comunicada mediante el Decreto de 9 de septiembre de 1861. Su objetivo básico fue restar poder económico a la institución eclesiástica quitándole parte de sus propiedades. Además, se buscó aliviar el déficit fiscal que tenía el Estado, permitiéndole a este obtener recursos con la venta de los bienes desamortizados $^{41}$. Aun así, lo obtenido no alcanzó para suplir las necesidades económicas ni las

40 De la desamortización se ha descrito básicamente el problema económico. Los principales textos son: Fernando Díaz Díaz, La desamortización de bienes eclesiásticos en Boyacá (Tunja: UPTC, 1977); “Estado, Iglesia y desamortización”, en Manual de Historia de Colombia, t. 2 (Bogotá: Procultura, 1984); Jorge Villegas, Colombia. Enfrentamiento Iglesia-Estado, 1819-1887 (Bogotá: La Carreta, 1981); Robert Knowlton, "Expropiación de los bienes de la Iglesia en el siglo XIX en México y Colombia: una comparación”, en El siglo XIX en Colombia visto por historiadores norteamericanos, comp. Jesús Antonio Bejarano (Bogotá: La Carreta, 1977); David Mejía Velilla, Glosas a la desamortización y otras páginas de historia (Bogotá: Universidad de La Sabana, 1998). Básicamente, el capítulo de este libro que tiene como título "Glosas a la desamortización”, siendo importante el recorrido histórico que hace de la desamortización en el mundo, explicándola conceptualmente.

41 La siguiente es la explicación que le dio al decreto uno de los responsables del mismo, Rafael Núñez, secretario de Hacienda, y quien, paradójicamente, sería uno de los artífices, como presidente del país en 1886, del proceso de conservadurización en el cual la Iglesia católica recibiría indemnizaciones por medidas como la desamortización: "La desamortización, puesta en actividad, ha sacado, puede decirse, de la nada todos los capitales que no lo eran ya sino una esperanza, y ha fomentado proporcionalmente el movimiento económico del país, procurándole también nuevos apoyos a la actual situación política. La desamortización no ha sido una medida de partido, en el sentido apasionado de esta palabra. Prueba irrecusable de ello es, que al mismo tiempo en que se disponían las ventas, se mandaba reconocer y admitir en ellas la deuda de la tesorería de la Confederación, cuyos dueños son, en la generalidad, antipáticos al presente régimen. Tampoco ha sido una medida de odio contra nuestras comunidades religiosas, aunque sea evidente que estas han perdido ya su razón de ser, como lo perdieron hace tiempo y desaparecieron, los Templarios y los Teutónicos. Prueba de ello es, que a todos los regulares que lo han solicitado se les ha pagado y se les sigue pagando con escrupulosa exactitud, y aun por anticipación, su respectiva renta [...] ¿Cuál es, pues, la expoliación, cuál es, pues, la impiedad, cuál es, pues, la inconveniencia e injusticia de esta gran Reforma?

En cuanto a la impiedad, la sangre cristiana que se ha derramado, en la parte central del país principalmente, por las sugestiones del interés mundano, envuelto en el sagrado manto de la Religión, y a pesar de la constante benevolencia del Gobierno con los revoltosos; dice suficientemente que no es, de ninguna manera, de nuestro lado que está la impiedad. No hay una letra en los Evangelios en virtud de la cual se pueda, no digo justificar, dejar de proscribir y condenar el derramamiento de una sola gota de sangre humana por cuestiones de casas i haciendas para el servicio del que es Padre de todos, Creador i dueño de todo, y cuya encarnación en la tierra fue el ejemplo vivo del desprendimiento de las cosas temporales”. Firmado en Bogotá el 14 de julio de 1862. El Colombiano (Bogotá), núm. 48, 25 de julio 1862, p. 189. Subrayados en el texto. 
deudas y sí consiguió fortalecer el latifundio en las zonas donde los laicos pudieron comprar los bienes que pertenecían a la Iglesia ${ }^{42}$. Se piensa que Mosquera también quiso con el decreto castigar a la Iglesia, y especialmente a las comunidades religiosas, que habían participado en la guerra civil a favor del gobierno de Ospina Rodríguez.

El considerando del decreto de desamortización explicaba los objetivos del mismo y las necesidades para tomar tal medida:

La falta de movimientos y libre circulación de una gran parte de las propiedades raíces, que constituían la base de la riqueza pública era uno de las mayores obstáculos para la prosperidad de la nación.

Igualmente, quedó decretado que las comunidades religiosas no podían poseer perpetuamente bienes raíces porque con ello atentaban al derecho constitucional que se tenía de acceder a los bienes. Por eso se determinó que todas las propiedades rurales y urbanas, los censos y las capellanías pasasen a la nación "por el correspondiente a la renta neta que en la actualidad producen o pagan, calculada como rédito al 6 por 100 anual; y reconociéndose en renta sobre el Tesoro, al 6 por ciento”33. Como también lo mostraron los siguientes artículos del decreto:

Artículo primero. Todas las propiedades rústicas y urbanas, derechos y acciones, capitales de censos, usufructos, servidumbres u otros bienes, que tienen o administran como propietarios u que pertenezcan a las corporaciones civiles o eclesiásticas y establecimientos de educación, beneficencia o caridad, en el territorio de los Estados Unidos se adjudican en propiedad a la nación por el valor correspondiente a la renta que en la actualidad producen o pagan, calculada como rédito al seis por ciento, en los términos de los artículos siguientes.

Artículo segundo. Bajo el nombre de corporaciones se comprenden de uno y otro sexo, cofradías y archicofradías, patronatos, capellanías, parroquias, cabildos, municipalidades, hospitales, y, en general, todo establecimiento y fundación que tenga el carácter de fundación perpetua o indefinida ${ }^{44}$.

42 A falta de trabajos profundos que nos dejen ver los impactos económico y social de la desamortización en Colombia, esta afirmación ha hecho carrera. Puede verse con claridad en el articulo de Álvaro Tirado Mejía, “Estado y política en el siglo XIX”, en Manual de Historia de Colombia, t. 2 (Bogotá: Procultura, 1983).

43 "Decreto de setiembre de 1861 sobre desamortización de bienes de manos muertas", en: Rejistro Oficial (Bogotá), año I, núm. 13, 11 de septiembre 1861, p. 55. Citado por: Díaz, “Estado”, 444. El considerando de la Ley Lerdo dice lo siguiente: “Que considerando que uno de los mayores obstáculos para la prosperidad y engrandecimiento de la nación, es la falta de movimiento o libre circulación de una gran parte de la propiedad raíz, base fundamental de la riqueza pública [...]”. Zarco, Historia, 597. Es grande la similitud entre el colombiano y el mexicano.

44 Restrepo, La Iglesia, 2: 61-62. Los artículos primero y segundo del decreto de desamortización colombiano son, en esencia, los mismos artículos primero y tercero de la Ley Lerdo. 
Nótese la gran similitud en las leyes de desamortización de Colombia y México, donde es evidente que en Colombia se copió no solo el espíritu sino también la letra de la ley mexicana.

Los bienes desamortizados no fueron únicamente los eclesiásticos, sino también bienes de cabildos y municipalidades, aunque los más afectados fueron los de la institución eclesiástica. No obstante, esta pensaba que dicha medida de desamortización de bienes de manos muertas era un duro golpe al sagrado derecho de propiedad. El proceso fue similar al de México en este sentido.

Para Tomás Cipriano de Mosquera, de acuerdo con lo que él mismo manifestó, era fundamental la redistribución de la tierra en función de su mejor empleo y de algún nivel de equidad social, aunque esto no ocultó su claro espíritu anticlerical. En un mensaje dirigido a los presidentes de los Estados -recordemos que para 1861 el país había optado por el federalismo-, les comunicó:

La propiedad ha estado mal constituida entre nosotros; fue constituida por un gobierno despótico, por la inquisición y el fanatismo, y por la aristocracia clerical y de sangre. Se constituyó, en consecuencia, oprimiendo a las clases trabajadoras en beneficio de los privilegiados. Pero esta constitución de la propiedad no es la que corresponde a un pueblo libre, digo, para usar de sus derechos no debe estar embarazado por estas trabas. Coloquemos, pues, la propiedad en consonancia con la democracia; demos, pues, la tierra a los que la trabajan y la hacen producir y dejemos la renta a los que tienen que consagrarse al estudio de las ciencias y el culto, y a todos aquellos que no pueden producir ${ }^{45}$.

La desamortización, tanto en México como en Colombia, generó posiciones encontradas. Unos la apoyaban por considerarla progresista, otros la veían como un claro ataque a los intereses de la Iglesia, con tintes anticlericales. Quienes estaban de acuerdo con la medida eran esencialmente los liberales adeptos a la administración de Mosquera, los liberales radicales y los que se beneficiaban económicamente con la libre circulación de los bienes que pertenecían a la Iglesia. Pero la medida tocaba algo más que el aspecto económico. Iba en contravía de la Iglesia, cuestionaba su poder material y le restaba riquezas para sostenerse. Por ello, la defensa de la medida pasaba por su importancia económica, por justificar que la institución eclesiástica no requería de mayores riquezas para sostenerse y por atacarla como instrumento de poder y no de devoción.

No era un secreto que concretar las reformas propuestas por liberales y conservadores requería de fondos suficientes, que estaban, en su mayoría, estancados en manos de la institución eclesiástica, o como bienes del Estado que no circulaban. La formación de un Estado fuerte y el mantenimiento de la burocracia requerían recursos.

45 Ibídem, 120-121. 
Además, la intención del presidente Mosquera de dividir las grandes extensiones de tierra, similar a lo propuesto por Zarco para México, justificaba la medida.

Económicamente hablando la medida envuelve una conveniencia pública, tan manifiesta y fecunda, que ni aun los mismos interesados en contradecirla, han indicado la menor duda respecto a ella, La reconocen, pues, como de inmensa .utilización para la Nación ${ }^{46}$.

Porque no se afectaba a particulares individuales: “[los] bienes y rentas no eran propiedad de un particular, sino que han sido adjudicados a un cuerpo de personas morales, por Soberanos, Señores, otras corporaciones o individuos, a objetos del culto" ${ }^{47}$. Y, siendo el culto muy importante, no se podía descuidar para encargarse de las riquezas, siendo esta otra justificación para la medida. ¿Cómo dejar de lado la función básica del clero regular o secular o de las comunidades religiosas para dedicarse a administrar riquezas? De tal forma que ellos eran solo tenedores de los bienes, pero no sus propietarios. Eran pues "meros usuarios de lo indispensable para su existencia, y nada más que administradores de todo los demás”48. Y lo indispensable no justificaba la posesión de riquezas excesivas y menos improductivas.

También, para defender la medida, se refutaban las afirmaciones según las cuales la Iglesia decaería, al perder la base de su sustento económico, ya que no habría cómo mantener el culto ni a los sacerdotes encargados del mismo, ni las comunidades religiosas tendrían cómo sostener obras de caridad o, por lo menos, alimentarse por sí mismas. Se argüía que no era de verdaderos sacerdotes o religiosos y religiosas preocuparse más por sus riquezas que por su misión espiritual y dejar sus funciones por falta de lujos y propiedades materiales. Lo cual, en última instancia, era una acusación de incumplimiento del deber y de interesarse por otros aspectos:

Abandonar el puesto que corresponde al Sacerdocio, en el culto y adoración de la Divinidad, por conservar, o no, casas, haciendas, animales o rentas, no solo deja de ser Católico, sino que envuelve un principio simoniaco, condenado por la Religión en todos los siglos ${ }^{49}$.

Por su parte, las posiciones opuestas a la desamortización de bienes tenían varios soportes. Se veía como una persecución contra la institución eclesiástica y, de forma más velada, como ataque al catolicismo. También se pensaba que era una forma de apropiarse indebidamente de los bienes para favorecer no solo al Estado sino también, y sobre todo, a los laicos sedientos de riquezas rápidas y baratas. Así las cosas, la

\footnotetext{
46 “Bienes de manos muertas”, El Colombiano (Bogotá), año 1, núm. 14, 30 de noviembre 1861, p. 54.

47 Ibidem.

48 Ibídem, p. 54.

49 Ibídem, núm. 13, 23 de noviembre 1861, p. 51.
} 
desamortización era vista como un mecanismo para conseguir el fin principal, que era “destruir primero el catolicismo, y después toda fe, toda creencia, toda conciencia, toda moral, todo orden”, y esto con el patrocinio de las leyes y las autoridades:

[...] nuestros famélicos reformadores [...] [se están] echando sobre los bienes de la Iglesia con una rapacidad y un descaro de que no hay ejemplo en los anales de nuestra desgraciada patria, y lo que peor es, sin provecho para el Gobierno dictatorial, supuesto que son unos pocos especuladores inmorales los que están medrando, y aun haciendo grandes fortunas ${ }^{50}$.

También, en la tónica de crítica a la medida, se propuso la excomunión para quienes comprasen los bienes que habían sido desamortizados. Para tal fin se implementó una red de información, donde laicos conscientes de los atropellos que significaba la desamortización informaban quiénes eran los responsables de los desalojos y las expropiaciones, y quiénes se postulaban para adquirir las propiedades.

\section{Libertad de conciencia y tolerancia de cultos en México}

El debate más candente y prolongado del congreso constituyente fue el del proyecto de artículo número 15, encaminado a aprobar la libertad de conciencia y la tolerancia de cultos $^{51}$. Según Emilio Rabasa, es probable que la sesión donde se votó la no aprobación del citado artículo haya sido a la que en mayor número asistieron los constituyentes presentes durante los trabajos del Congreso, es decir, 110 de los 155 constituyentes elegidos ${ }^{52}$. En relación con este artículo, se podían distinguir básicamente dos posiciones: la de quienes lo defendían y consideraban oportuno y la de quienes lo atacaban. En este último grupo estaban los sectores conservadores, pero también liberales radicales o puros, que sentían que estaba redactado de forma ambigua y no alcanzaba lo que pretendía.

Si bien muchos afirmaban que la libertad de conciencia era la más preciada de las libertades, la discusión se encaminó hacia la manifestación material de esa libertad, es decir, hacia la libertad de cultos. En esencia, todos los constituyentes estaban de acuerdo con la libertad de conciencia como un bien inherente a los seres humanos; sin embar-

50 Boletín Noticioso (Bogotá), núm. 5, 4 de noviembre 1862, s. p.

51 El proyecto de artículo 15 decía así: “No se expedirá en la República ninguna ley ni orden de autoridad que prohíba o impida el ejercicio de ningún culto religioso; pero, habiendo sido la religión exclusiva del pueblo mexicano la católica, apostólica, romana, el Congreso de la Unión cuidará, por medio de leyes justas y prudentes, de protegerla en cuanto no se perjudiquen los intereses del pueblo ni los derechos de la soberanía nacional”. Francisco Zarco, Debate en el Congreso Constituyente, 1856-1857 (México: Centro de Investigación Científica Ing. Jorge L. Tamayo, 1991,) 91. Daniel Cosío afirma que el debate del Artículo 15 fue el más prolongado y de más largo aliento. Daniel Cosío Villegas, La Constitución de 1857 y sus críticos (México: Clío, 1997), 63.

52 Emilio Rabasa, La constitución y la dictadura. Estudio sobre la organización política de México, 3 ed. (México: Porrúa, 1956), 33. 
go, se enfrentaban en lo oportuno o no de permitir manifestaciones religiosas diferentes a las del catolicismo. Es decir, el punto de choque estaba en si era saludable o no para el país permitir que ingresaran a él denominaciones religiosas diferentes a la católica, apostólica y romana.

Primero observemos las posiciones contrarias expresadas por los constituyentes en las sesiones plenarias del Congreso. Ellas las podemos dividir en otras, como quedó dicho: los que creían que el texto estaba redactado de forma ambigua y los que pensaban, en su mayoría conservadores, que el proyecto atacaba las bases fundamentales de la sociedad. Entre los primeros contamos a Francisco Zarco, quien solicitó al Congreso dividir el artículo en dos partes para su estudio: la primera, dedicada al ejercicio de cualquier culto religioso, y la segunda, dedicada a la religión católica; propuso, también, redactar la primera parte del mismo en forma afirmativa y no negativa, y suprimir la segunda parte, pues no entendía por qué se debía proteger a una religión específica, la católica.

El catolicismo, la revelación, la verdad eterna -afirmaba Zarco-, no necesita de la protección de las potestades de la tierra, no necesita del favor de los reyes, ni de las repúblicas: por el contrario, la verdad católica es la que protege al género humano ${ }^{53}$.

La verdad cristiana se asemejaba a la democracia porque proclamaba la libertad, la igualdad y la fraternidad de todos los hombres. En este punto pasó a distinguir entre religión y clero. Para él, este último era enemigo de la libertad, porque acumulaba riquezas, engañaba a los pueblos, generaba guerras y defendía privilegios. Por ello, el artículo no podía ser aprobado ya que favorecía al clero, protegiéndole su fuero. Además, proteger al clero significaba darle importancia y fortaleza a la reacción y al fanatismo, poniendo en peligro la soberanía nacional. La protección de un culto específico, como estaba plasmado en el proyecto de artículo, según Zarco, generaba hostilidades hacia los demás credos, cayendo en el peligro, incluso, de una religión de Estado ${ }^{54}$. Para solventar el inconveniente, Zarco propuso la siguiente redacción: "la república garantiza el libre ejercicio de todos los cultos. Así, señores, se proclamaría el principio con valor y con claridad”55.

Una de las características de quienes no estaban de acuerdo con medidas que favorecieran a la Iglesia católica era que buscaban mostrarse como católicos, queriendo con ello evitar cualquier discusión que los mostrase ante la opinión como contrarios al credo histórico de México. Por ello buscaban diferenciar entre clero y religión. Zarco, por ejemplo, se mostraba como católico:

\footnotetext{
53 Zarco, Historia, 804.

54 Zarco, Debate, 94-95.

55 Zarco, Historia, 803.
} 
[...] no puedo olvidar jamás que los labios de una madre querida me enseñaron las verdades del catolicismo [...] y que la religión, señores, con sus consuelos y esperanzas, daba serenidad al hogar doméstico en los días de mi infancia ${ }^{56}$.

Según él, la fe en Dios hizo que el pueblo resistiera la más oprobiosa de las tiranías, refiriéndose a la de Santa Anna. Además, en la vida individual, llena de sobresaltos y transformaciones, Dios es una compañía valiosa.

Otro constituyente, Guillermo Prieto, tampoco compartía la redacción del artículo, pues consideraba que debía declararse la libertad de conciencia sin más. Por el contrario, el artículo protegía con leyes únicamente a la religión católica. El debate daría como resultado, según él, la confrontación entre civilización y barbarie:

Al decretar la libertad de conciencia solo se declara que las relaciones del hombre para con Dios no son de nuestra jurisdicción, que la ley no ha de invadir el sagrado de las conciencias, que nadie ha de ir a contar los granos de incienso que se consagran al Señor ${ }^{57}$.

José María Cortés Esparza, representante de Guanajuato, afirmaba, oponiéndose a la redacción del artículo, y dejando en claro, como Zarco y otros, que también era católico, que ninguna autoridad terrestre podía intervenir en las relaciones del hombre con Dios: "La ley no puede hacer una religión; que la ley no puede mezclarse en estas materias sin hacer hipócritas, porque la religión es un sentimiento que nace del corazón”58.

Se dieron otras posiciones entre los constituyentes, manifestadas en la plenaria del Congreso; en ellas la crítica al artículo se centraba, esencialmente, en tacharlo de enemigo de la religión católica y de desear quebrar la unidad nacional con la tolerancia de cultos. El constituyente Mariano Arizcorreta, representante del Estado de México, no acogía el artículo tal como estaba planteado. Para él, la libertad de conciencia no podía ser regulada por los hombres, ya que solo competía a Dios. Por otro lado, y este es el punto más importante, rechazaba la manifestación pública de la libertad de cultos debido esencialmente a que esta debía ser limitada y estar sujeta a la acción y vigilancia de la ley y de la sociedad. En este orden de ideas, Arizcorreta defendía la función que había desempañado la Iglesia católica. Según él, las costumbres habían mejorado con el catolicismo y la evangelización. El hombre conoció por el catolicismo la altura

56 Ibídem, 802.

57 Ibídem, 820. En la Nueva Granada, cuando se discutía el problema de la tolerancia religiosa, también se llegó al debate sobre la civilización y la barbarie: “Abrid al fin los ojos, y si no por la Religión, obrad de otra manera por vosotros mismos: la intolerancia es prueba de barbarie; un pueblo intolerante, es un pueblo salvaje; las naciones menos intolerantes, son más civilizadas, y prosperan más”. Véase: “Observaciones sobre la lei de Junio de 1853”, El Neogranadino (Bogotá), 18 de agosto 1853, pp. 296-297. 
de su dignidad: "El catolicismo, Señor, conquistó en el mundo la igualdad"59. Esto lo afirmaba porque en el templo, ante Dios, todos los hombres eran iguales. Nótese lo interesante del planteamiento: si bien en el templo todos los hombres son iguales ante Dios, los principios liberales buscan que sea ante la ley que se plasme esa igualdad.

Por lo tanto, si el catolicismo era la religión que había permitido el progreso del pueblo mexicano, no se entendía la necesidad de la tolerancia de cultos. Arizcorreta explicó este punto de la siguiente manera:

Esta huella hermosa de humanidad, de libertad, de igualdad y civilización -refiriéndose al catolicismo-, no debe abandonarse, sino seguirse cuando trata de conquistarse el principio de la democracia; no debe perderse ni un ápice esta unidad de acción tan conocida y que nos guiará a la conquista del principio, y no debe por lo mismo menoscabarse, mezclando en la sociedad aspiraciones apasionadas de cultos egoístas, intolerantes y aún bárbaros, inmundos y supersticiosos, como se pretenden con la generalidad en que está concebido el artículo a discusión ${ }^{60}$.

Se entiende que posiciones como las de Arizcorreta estuviesen encaminadas a menospreciar y criticar otras expresiones religiosas, diferentes al catolicismo, pues la crítica se basaba en el rechazo a otras creencias y en la tradición católica del pueblo mexicano:

¿Qué reforma es esta, que reorganiza en la sociedad la mezquindad y suciedades asquerosas de la idolatría y el paganismo, la ferocidad y la tiranía del islamismo, la obcecación pirrónica del judaísmo, el egoísmo y la intolerancia del protestantismo, en un pueblo acostumbrado por siglos en su culto religioso a ideas y sensaciones de gloria, de humanidad, de paz, de amor y de consuelo ${ }^{61}$ ?

En la misma tónica, el constituyente Prisciliano Díaz González, representante del estado de México, apoyó la libertad de conciencia aduciendo que ella venía del corazón y este pertenece al hombre:

[...] pero sabemos también que el culto externo pertenece a la sociedad, pertenece al pueblo, a ese pueblo que amamos, a ese pueblo que respetamos y del que somos hijos. Cada hombre en el secreto de su corazón, levante los templos que guste, inciense al Dios que conciba; pero este hombre respete el culto externo de la sociedad, que no es mejor un hombre que todo un pueblo ${ }^{62}$.

58 Zarco, Historia, 812.

59 Ibídem, 828.

60 Ibídem, 829.

61 Ibídem, 832.

62 Ibídem, 838. 
El problema consistió, como se ve, en la manifestación pública de los cultos, lo que mostraría la presencia de sujetos con otras creencias que de una u otra forma pusieran en peligro la tradición religiosa del pueblo mexicano. Por ello mismo, y por considerar que el catolicismo era la religión de los mexicanos, Díaz González afirmaba que para el pueblo mexicano "el culto católico es su culto y no pretende mudarlo ni alterarlo" ${ }^{6}$.

Por su parte, el constituyente Juan Barragán, del estado de San Luis Potosí, advirtió que si bien se respetaba la libertad de conciencia, una asamblea católica no debía permitir la existencia de otros cultos, esencialmente porque en México no había un número elevado de protestantes ${ }^{64}$. El temor de los mexicanos que veían cómo se perdería el monopolio evangelizador por parte de la Iglesia católica también radicó en los resultados de la tolerancia de cultos. Con mentes altamente imaginativas, creían que el país caería en una especie de Torre de Babel de cultos. Arizcorreta ponía el ejemplo: si un mexicano abrazaba la fe del islam, podía, desde luego, “ejercer libremente la poligamia, y poner su harem”. Con ello se romperían "los lazos más dulces y tiernos, los de la familia, que son el elemento constitutivo del vínculo social”65. Díaz González creía que era necesario defender la religión del pueblo; por ello, en tono casi escatológico, afirmaba que moriría tranquilo al saber que atacó la tolerancia de cultos, con estas palabras: "proclamé el fallo de la conciencia pública, porque defendí la causa del pueblo y con ella la causa de Dios”66. Aunque el asunto podía ir más allá de la defensa de principios personales. La recurrencia a la guerra civil era constante en estos debates. Arizcorreta creía que, de aprobarse el artículo, ello podía causar "una conflagración en la sociedad”67.

Por el contrario, los constituyentes defensores del artículo veían que era oportuna su aprobación. Para ello emplearon varios argumentos: la necesidad de promover la migración extranjera y de estar al día con otras naciones del continente que ya habían adelantado en esta materia ${ }^{68}$. Debemos tener en cuenta que este artículo puede ser visto como un avance hacia la modernidad política y la caída de las estructuras, aún existentes, del mundo colonial. Para el constituyente González Páez fue claro que el artículo era necesario para promover la migración extranjera, fundamental por "su amor al trabajo". Un punto central en la defensa fue el de patrocinar la migración

\footnotetext{
63 Ibídem, 840.

64 Ibídem, 867.

65 Ibídem, 830.

66 Ibídem, 844.

67 Ibídem, 831.

68 Este argumento no fue original de los constituyentes de 1857. Años antes había sido expresado, entre otros, por José María Luis Mora, quien, como embajador mexicano en Londres inició gestiones, a mediados del siglo XIX, para promover migración británica. Según Mora, la migración podía haber evitado guerras como la de castas en Yucatán o la de Texas que le costó a México la pérdida de ese territorio. Hale, El liberalismo, 216-217.
} 
extranjera: “[...] entre todas esas concesiones ha faltado una, la de que cada cual pueda adorar al dios de sus padres; la de que cada cual pueda profesar la religión en que fue educado" ${ }^{69}$. Según Zarco, por falta de migración México perdió buena parte de sus territorios -esta posición es muy similar a la que manifestó años antes Mora:

Por nuestra intolerancia perdimos a Texas, perdimos la Alta California, perdimos la Mesilla, y si no admitimos la colonización que nos conviene, tal vez perderemos nuestra nacionalidad y nuestra independencia, salvando lo que se llama la unidad religiosa ${ }^{70}$.

Zarco introdujo en la discusión un punto interesante: la intolerancia de los mexicanos hacia cultos religiosos diferentes al católico, lo que haría mostrar de una u otra forma la intolerancia hacia los extranjeros. El debate por la libertad de cultos podía mostrarse como un hecho muy práctico y tangible para el desarrollo histórico de México, y como una crítica fuerte a quienes estaban contra el desarrollo del país. En primera instancia, el constituyente Jaquez señaló la inconsistencia del mexicano, que quería la libertad de conciencia para él en Inglaterra, en Suecia, en Rusia, en Japón, en China, pero no le concedía la misma libertad a los ingleses, a los suecos, a los rusos o a los chinos. Advirtió que en el país los altos dignatarios promovían la igualdad, pero evitando a toda costa que otros hombres gozasen de los mismos derechos que ellos, rechazando a los hermanos del mundo; se deseaba el progreso pero se ponían trabas a la inteligencia, que muy probablemente viajaría con los inmigrantes ${ }^{71}$. La posición era interesante porque mostraba la incongruencia e inconsistencia de los discursos, sobre todo liberales, aunque también, en este caso, conservadores, ya que la mayoría de integrantes de ambos bandos políticos estaban a favor de la libertad de conciencia pero en contra de sus manifestaciones materiales.

En este punto, la discusión se encaminó a mostrar que el problema de la libertad de conciencia y su producto material, la tolerancia de cultos, trascendían lo religioso para entrar al campo de lo puramente político y social. Y en este terreno se veía al clero y a sus aliados, los conservadores, como los intolerantes. Para el constituyente García Granados la intolerancia hacía recordar la "hoguera humeante aún de la inquisición, con todos sus horrores”72. La intolerancia conducía a que “¡Los cadáveres de los protestantes debían ser arrojados al campo para que fueran pasto de las aves de rapiña! [...]"’3. Mientras no se lograse controlar a estos intolerantes no sería posible el progreso del país. Así lo creían los defensores acérrimos del artículo, los señores

69 M. del Castillo, "Libertad de Cultos”, Monitor Republicano, núm. 3103, 6 de marzo 1856, p. 1. Citado por Jacqueline Covo, Las ideas de la Reforma en México (1855-1861) (México: UNAM, 1983), 190.

70 Zarco, Historia, 807.

71 Ibídem, 841.

72 Ibídem, 844. 
Mata y Gamboa, para quienes no era concebible que no se lo aprobase porque estaba elaborado para un pueblo que era tratado como ignorante. Pero esa ignorancia se debía, esencialmente, a la manipulación del clero sobre la sociedad. Mata preguntaba:

\begin{abstract}
¿Y cuando [...] estaría [preparado el pueblo], a vuestro juicio? [...] Cuando el pueblo deje de ser bárbaro, cuando deje de ser ignorante, cuando deje de ser fanático, cuando deje, en fin, de ser supersticioso. Entonces, habéis dicho, será tiempo, porque ahora el pueblo no sabe y como solo vosotros sabéis, en vuestra alta sabiduría, habéis decretado que el pueblo será vuestro obligado, que esté bajo vuestra tutela ${ }^{74}$.
\end{abstract}

En esta parte es interesante mostrar cómo los constituyentes de 1856 hacían referencia continúa al caso de la Nueva Granada como ejemplo de progreso en esta materia. El constituyente Cerquera hizo alusión al caso colombiano de la siguiente manera:

La república de Colombia, educada bajo el fanatismo y las preocupaciones españolas, hizo otro tanto -refiriéndose también al caso de Estados Unidos-, consiguiendo así que la tolerancia religiosa se estableciera con asombro de la Europa toda, que veía adquirida una conquista difícil en el campo de la reforma, sin chocar de frente con las arraigadas costumbres teocráticas que todo lo habían invadido ${ }^{75}$.

Para Francisco Zarco, la Nueva Granada también era un ejemplo a seguir, pues era "el país más progresista de América española”76, seguramente haciendo referencia a la serie de medidas que se comenzaron a aplicar desde comienzos de la década de 1850. Nótese que a pesar de la similitud entre Cerquera y Zarco, hay una diferencia en sus posiciones. Para Cerquera, Colombia era un país lleno de fanatismo por la influencia española, y por ello la legalización de la tolerancia religiosa fue tomada con asombro en Europa, mientras que para Zarco, a pesar de la influencia del fanatismo español, la Nueva Granada había alcanzado el progreso, hasta convertirse en el más progresista del continente. Sin embargo, recordamos que la tolerancia religiosa en Colombia no fue una panacea, como pudieron pensar los mexicanos contemporáneos.

El proyecto de artículo 15 fue rechazado en votación plenaria del Congreso. De allí fue remitido a la comisión de Constitución, que intentó rehacerlo para devolverlo al

73 Ibídem, 845.

74 Covo, Las ideas, 186-187. Sin embargo, el proyecto fue definitivamente derrotado en la votación del 26 de enero de 1857, por 67 votos contra 22. Francisco Zarco mostraba su decepción en su Crónica del Congreso: "Quedó, pues, perdida la causa de la libertad de cultos, perdida en la asamblea, en las regiones oficiales, allí donde reinan lo que se llama prudencia, moderación, juicio, etc. [...] pero la misma causa quedó triunfante en la opinión. La votación fue triste. No parecía sino que el Congreso se arrepentía de haber discutido el principio; pero en este mea culpa, había algo de timidez, de confusión y, digámoslo todo, de vergüenza”. Véase: Crónica del Congreso Constituyente (México: El Colegio, 1957), 905. Citado por Covo, Las ideas, 196. 
pleno; sin embargo, lo que quedó de esa revisión distaba mucho de lo inicialmente propuesto. El artículo, que al final se aprobó por una mayoría aplastante de 82 votos contra 4, fue el número 123: "Corresponde exclusivamente a los poderes federales ejercer, en materias de culto religioso y disciplina externa, la intervención que designan las leyes" "77. Según Emilio Rabasa, los liberales moderados se alejaron de los puros o radicales en esta materia y prefirieron abstenerse de votar a favor la libertad de conciencia. Citando a Zarco, afirmó:

Tan breve debate, tan considerable mayoría, son la mejor prueba de que no se ha conquistado ningún principio importante. Las relaciones entre la Iglesia y el Estado quedaron como antes; es decir, subsisten la lucha y la controversia entre los dos poderes ${ }^{78}$.

La afirmación de Zarco citada por Rabasa debe ser tomada con cautela, pues la sola presencia de ese artículo 123 en la nueva Constitución generó en la opinión pública diversas reacciones. Las más fuertes fueron las de la jerarquía de la Iglesia. El obispo de Guadalajara, Pedro Espinoza, se preguntaba:

[...] ¿podrá creerse conveniente agregar a nuestras luchas fratricidas la de los protestantes que, admitiendo el desatentado y funesto principio de orgulloso examen, sepultarán de seguro a nuestra juventud en esa vaguedad indefinible que mueve el alma en todas direcciones ${ }^{79}$ ?

Aludía a que con la libre interpretación de las escrituras podrían llevar a la corrupción moral de la juventud mexicana y a una guerra con connotaciones religiosas. Por su parte, el obispo de Morelia, Munguía, iba más allá en sus críticas, al reprocharle a la Constitución la total ausencia de menciones explícitas a la religión y a la Iglesia católicas. Sobre el artículo en cuestión, decía:

[...] que nada reconoce, que nada consigna, que nada garantiza en materia de culto, pues no dice cuál es la religión del país, cuál es la religión del Estado, qué derechos tiene, con qué seguridades cuenta; borra al parecer, todos los títulos de la religión católica, desnaturaliza su carácter, destruye sus derechos y la mata, digámoslo así, en su confuso recuerdo ${ }^{80}$.

\footnotetext{
75 Zarco, Historia, 847.

76 Zarco, Debate, 109.

77 Las constituciones, 159. Sobre este tópico, véase Villegas, El liberalismo, 154.

78 Rabasa, La constitución, 49.

79 Pedro Espinoza, “Séptima carta pastoral que el Ilmo. Sr. Dr. D. Pedro Espinoza, obispo de Guadalajara dirige a sus diocesanos”, pp. 12-13, Colección Lafragua, UNAM. Citado por Villegas, El liberalismo, 153-154.

80 Munguía, En defensa, 75.
} 
Era evidente el temor que despertaba entre la jerarquía de la Iglesia la posibilidad de perder la exclusividad religiosa en México, lo que abría la puerta a la presencia de otras denominaciones religiosas. Al final, la tolerancia religiosa fue legislada hacia 1860, en medio de la Guerra de Reforma, tal vez como una manera de golpear a la Iglesia por el apoyo prestado a los conservadores en ese conflicto.

\section{Libertad de cultos en la Nueva Granada ${ }^{81}$}

Esta libertad quedó reglamentada en la Nueva Granada en la Constitución de 1853. En el capítulo primero, referente a la República de la Nueva Granada y a los granadinos, el inciso 5 del Artículo 5 afirmaba lo siguiente:

La república garantiza a todos los granadinos: la profesión libre, pública o privada de la religión que a bien tengan, con tal que no turben la paz pública, no ofendan la sana moral, ni impidan a los otros el ejercicio de su culto ${ }^{82}$.

Esta libertad iba acompañada de otras del mismo tenor: libertad individual, seguridad personal, inviolabilidad de la propiedad, libertad de industria y trabajo, para solo mencionar algunas.

Desde la Independencia el tema de la tolerancia fue recurrente en la Nueva Granada. A mediados de 1848, se firmó un tratado con Estados Unidos, que buscaba, entre otros aspectos, fomentar el espíritu de tolerancia anhelado por los liberales. El 22 de noviembre de 1852, Florentino González, reconocido por ser el impulsor del libre cambio en el país en la década de 1840, publicó en el periódico bogotano El Neogranadino un artículo en el cual exponía su posición respecto al problema entre Iglesia y Estado en el país. En él, González dejaba en claro que el Estado solo se fortalecería cuando el pueblo participara de manera activa en el gobierno, es decir, teniendo la oportunidad de elegir a sus gobernantes. Por ello el gobierno decretaba el sufragio universal y secreto, para que consecuentemente el pueblo estuviese representado en los políticos que eligiese libremente. Por tanto, para el gobierno liberal era de vital importancia proclamar, proteger y defender la libertad de conciencia, hecho que finalmente redundaría en el bienestar y el progreso del país. Libertad de conciencia que abarcaba no solo el ámbito religioso sino el político, es decir, protegiendo al ciudadano de cualquier coacción que uno u otro político quisiese ejercer para su beneficio electoral. No es gratuito que la libertad de conciencia se discutiera de forma paralela a la proclamación del voto universal para los hombres. En este punto es importante mostrar la

81 Las fuentes para el caso neogranadino, excepto las referentes a las Constituciones políticas, han sido tomadas de la monografía de pregrado en Historia que adelanta actualmente Andrey Arturo Coy, “Tolerancia religiosa en Bogotá y la revolución liberal de Medio Siglo (1849-1854)” (Monografía de pregrado en Historia, Universidad Nacional de Colombia, Bogotá, 2004).

82 Constituciones de Colombia, recopiladas y precedidas de una breve reseña histórica por Manuel Antonio Pombo y José Joaquín Guerra (Bogotá: Ministerio de Educación Nacional, 1951), 4: 7. 
coincidencia con algunos constituyentes mexicanos, para quienes la libertad de conciencia traería progreso a su país, tal como fue expuesto en páginas precedentes.

Florentino González creía que la mejor garantía para la supervivencia y el mantenimiento de la República era establecer y proclamar la mencionada libertad de conciencia y, por ello mismo, una de sus consecuencias, la libertad religiosa, expresada en la tolerancia de cultos ${ }^{83}$. La libertad de conciencia permitiría que existiese el sustento moral para que la libertad individual y de pensamiento fuesen realidades tangibles para la sociedad neogranadina de aquel momento.

González postulaba como ejemplo político del avance de la libertad de conciencia a Estados Unidos. Para él, era allí donde el sistema republicano había encontrado su mejor expresión:

La combinación que ofrezco al examen de mis compatriotas no es una utopía, fruto de la veleidad de mi entendimiento. Es por el contrario, el resultado de meditaciones detenidas sobre lo que he visto en práctica en la Nación afortunada que fundó el inmortal Washington secundado por sus ilustres compañeros. De estas meditaciones ha nacido la profunda convicción de que aquellas instituciones contienen el germen del bien y lo desarrollarán en donde quiera que se adopten ${ }^{84}$.

Varios años después, y como vimos atrás, los constituyentes mexicanos de 1856 mostraban a la Nueva Granada como un ejemplo a seguir, tal como González lo hizo, en la Nueva Granada, con Estados Unidos.

La libertad religiosa fue aprobada en la Constitución de 1853, pero no pasó indemne entre la opinión pública y entre la misma administración estatal. Como en México, la sola idea de quitarle el monopolio a la religión católica generó en la Nueva Granada reacciones de rechazo. Los redactores del periódico La Religión protestaron por la aprobación de leyes que afectaban a la Iglesia católica, calificandolas como corrupto-

83 El siguiente texto muestra el pensamiento de Florentino González acerca de la libertad religiosa y cómo esta era importante para el país: "La declaración a favor del ciudadano de la libertad individual, de la libertad de industria, de la libertad de prensa, de la libertad de reunirse y expresar su opinión, de la libertad religiosa; es decir, la competencia exclusiva del individuo para decidir de todo lo relativo a estas cosas, es igualmente una garantía para el establecimiento y conservación de la Republica. El asegurar la libertad religiosa, sobre todo, es tan esencial para la conservación del gobierno republicano, que sin ella, no puedo concebir la existencia de aquel. El despotismo sombrío que por tantos siglos ha dominado el mundo, ingenioso en la invención de los medios de sostener un poder no basado sobre la voluntad del pueblo, incrustó la religión en el gobierno, con el pretexto de ejercer un derecho que llamo de tuición, de inspección y de defensa, y más tarde patronato. Entonces los ministros de la religión, convertidos en funcionarios políticos, fueron los oficiales del estado civil en todas las poblaciones al mismo tiempo que ejecutaban las ceremonias del culto y se presentaban al pueblo como los Oráculos del Cielo”. En: “A los legisladores de 1851”, El Neogranadino (Bogotá), 31 de diciembre 1852, p. 333.

84 Ibídem. 
ras e impías. La protesta insistía en que las autoridades eclesiásticas no podrían vigilar la importación y circulación de obras que llevasen a la corrupción del pueblo, como lo eran las biblias protestantes, que se vendían a precios muy bajos o eran regaladas. De allí que, como pasó en México con constituyentes como Marcelino Castañeda, los editorialistas del citado periódico reclamasen el restablecimiento de la Constitución de $1843^{85}$, en donde el Estado protegía a un solo credo religioso, el católico, declarando, a la vez, como escandalosa la libertad religiosa:

¡La diversidad y variedad de religiones en una República eminentemente cristiana, que ha mantenido más de 300 años el culto que se tributa al único y verdadero Dios, es el escándalo más asombroso que puede presentar el legislador cristiano ${ }^{86}$ !

Para los editorialistas de La Religión establecer la tolerancia de cultos tanto para nacionales como para extranjeros era un acto de tiranía y crueldad, máxime en un país donde la religión católica, que era consideraba de por sí la verdadera, era la dominante. Para ellos “una religión tolerante no es un culto, es la destrucción de todos los cultos”. La tolerancia era, por lo tanto, la mayor prueba de desprecio del hombre por la verdad. El problema de la tolerancia radicaba en que para los católicos aquella era hija de la indiferencia ${ }^{87}$. Un poco menos intolerantes, para los editores de El Catolicismo (el periódico más antiguo y vigente del país, fundado en 1849) era menester derogar todas las disposiciones que en materia legislativa interfiriesen en los asuntos religiosos de la Nueva Granada. Según ellos, los católicos nunca pidieron la libertad de cultos, pero teniéndolo ya como asunto sobre el cual se había legislado, nada podían hacer en su contra ${ }^{88}$.

Por último, se percibía que la intolerancia podía conducir a cualquier Estado o nación a la anarquía social, idea similar a la presente en México.

La libertad religiosa jamás ha excitado guerras civiles: "la intolerancia ha cubierto a la tierra de cadáveres”. Una media libertad no es libertad. Yo la quiero toda entera: libertad de agricultura, de comercio, de artes, de imprenta, de cultos. A nombre de la Constitución nosotros hemos jurado y prometido a todas las naciones del mundo libertad de cultos en un derecho consagrado por el Congreso de 1853: un derecho fundado sobre la naturaleza. Sostengámoslo; pero regularicémoslo [...] Debemos decir como hombres públicos y como hombres mo-

85 El título IV de la Constitución de 1843, "De la Religión de la República”, decía que: "La Religión católica, Apostólica, Romana es la única cuyo culto sostiene y mantiene la República”. Constituciones de Colombia, 3: 334.

86 “La Constitución y la Iglesia”, La Religión (Bogotá), 24 de mayo 1853, p. 87.

87 Ibídem, 24 de junio 1853, pp. 95-96 y 7 de julio 1853, pp. 99-100.

88 “Libertad Relijiosa [sic]”, El Catolicismo (Bogotá), 1 de junio 1853, pp. 765-767. 
rales: Ama a tu Dios y a tu prójimo como a ti mismo, y no quieras para otro lo que no quieras para ti. Dogmas son estos que nadie puede rechazar $[\ldots]^{89}$.

\section{Conclusiones}

México y la Nueva Granada vivían, a mediados del siglo XIX, años muy convulsionados. Esos años estuvieron marcados por el planteamiento de reformas de corte liberal que buscaban fortalecer el naciente Estado en materia jurídica, económica y política y generar condiciones, formales y materiales, para la igualdad de los hombres ante la ley. Libertades como la de conciencia, manifestada en la libertad de cultos, y medidas como la desamortización, el desafuero, la separación Iglesia-Estado, entre otras, hacían parte de un amplio programa liberal, de tal forma que las reformas que hemos estudiado aquí no pueden entenderse aisladamente sino en un conjunto más amplio de procesos sociales, políticos y económicos. Por ejemplo, el solo hecho de modificar el sistema de justicia, eliminando los privilegios que significaban los fueros, era clara muestra de los principios liberales de igualdad jurídica. La desamortización, por su parte, mostraba la necesidad de fomentar una economía más dinámica, acorde con los cambios económicos y las transformaciones generadas por lo que Eric Hobsbawm ha denominado la doble revolución, la económica y la política, de finales del siglo XVIII y del siglo XIX.

En México y la Nueva Granada se vio la necesidad, al plantear las reformas, de someter a la Iglesia católica a la ley civil, reduciéndole su espacio de acción social y quitándole los privilegios que había heredado desde la Colonia. Esa necesidad se había observado previamente en México hacia las décadas de 1830 y 1840. Pero en ninguna de esas oportunidades se habían obtenido los resultados deseados. La Constituyente de 1856-1857 fue, podríamos decirlo, un parteaguas en el planteamiento de reformas liberales, esencialmente porque comprometió en su redacción a diversos sectores políticos que se estaban perfilando en ese entonces, como liberales, conservadores y moderados, y porque canalizó propuestas y leyes que buscaban, como quedó dicho atrás, fortalecer al Estado en detrimento del poder de la Iglesia. Entre tanto, en la Nueva Granada también se intentó en repetidas oportunidades disminuir el poder de la Iglesia. Por ejemplo, en la década de 1820 el vicepresidente Francisco de Paula Santander planteó la necesidad de revivir el Patronato y patrocinó el arribo de misioneros protestantes. Ninguna de las dos medidas fructificó. Ya en 1843, y en la Constitución promulgada ese año, la religión católica se convirtió en la oficial de la nación, lo que le restó posibilidades a reformas en materia religiosa. Solo sería hasta la década de 1850 que liberales jóvenes y algunos caudillos herederos de la Independencia se dieran a la tarea de construir un proyecto de Estado con características liberales, para lo cual debieron debilitar a la Iglesia, en la medida que ella podía competir,

${ }_{89}$ Gaceta Oficial (Bogotá), 3 de marzo 1855, p. 567. 
institucionalmente hablando, a ese naciente Estado. Para lograrlo, es decir, para socavar su poder ideológico, económico y social, eran necesarias las reformas liberales.

El planteamiento de las reformas no pasó inadvertido; por el contrario, generó fuertes discusiones y agrias protestas en sectores defensores de la Iglesia y en ella misma. Los motivos que se presentaron en ambos países para defender la posición de la Iglesia ante la arremetida liberal son similares, lo que también nos muestra que ella, en su conjunto, sin importar las fronteras, sentía los mismos peligros, las mismas amenazas, y veía los mismos enemigos. En México, los sectores conservadores y proclericales se alzaron en armas contra las leyes que estaban siendo promulgadas por la administración de Juan Álvarez, tras la caída de Santa Anna. Como respuesta a ese levantamiento armado, la administración se vio abocada a la guerra civil, como sucedió en Puebla. Tras la promulgación de la Constitución, los conservadores y los moderados, con el apoyo de la Iglesia, buscaron echar atrás las medidas adoptadas en la Carta Magna, para lo que se valieron del golpe de Estado. Para defender la institucionalidad, los liberales afrontaron una guerra civil de tres años, conocida como la Guerra de Reforma. El conflicto bélico hizo que los liberales radicalizaran su posición contra la Iglesia y tomaran medidas más drásticas, como la nacionalización de los bienes eclesiásticos. Si los liberales hubiesen perdido esa guerra, lo que habría significado el triunfo conservador, habría sido muchísimo más difícil el advenimiento del Estado laico y la secularización en México. Pero ello no sucedió así, y las reformas asumidas en la Constitución de 1857 se proyectaron hasta el porfiriato, y de allí hasta el siglo XX, permitiendo la consolidación de la separación entre Iglesia y Estado y la laicidad de este. A pesar de que en el porfiriato se llegó a cierta conciliación con la Iglesia, la Revolución Mexicana y la posterior guerra cristera radicalizaron nuevamente las posiciones, de tal forma que Estado e Iglesia siguieron su propio camino a lo largo del siglo XX.

Entre tanto, en la Nueva Granada las reformas no prosperaron. A pesar de que las más importantes, como la desamortización, fueron impuestas tras una guerra civil en donde los conservadores, apoyados por la Iglesia, fueron derrotados, y de que la Constitución de 1863 dejó sentadas las bases para la secularización, la administración liberal radical se fue debilitando, tanto que aun después de salir victoriosa en la guerra de 1876-1877, fue derrotada definitivamente, por la vía electoral, dándole paso a los liberales independientes y a los conservadores para que, por medio de un proyecto político plasmado en la nueva Constitución de 1886, retomasen a la Iglesia como una fuente de sustento ideológico para el Estado. Así, comenzando el siglo XX, la Iglesia era el mayor sustento ideológico del Estado conservador, aspecto este que no se presentó en México.

Para finalizar, podemos afirmar que la constituyente de 1856-1857 y la Constitución de este último año marcaron el sendero que seguirían las relaciones Iglesia y Estado 
por un buen tiempo, mientras que en Colombia las reformas no prosperaron por múltiples motivos, ya sea por la inconsecuencia de los liberales que las propusieron, por la férrea oposición de sectores conservadores o porque no existían los suficientes recursos económicos y humanos para concretarlas, lo que desembocó, a finales del siglo XIX, en un régimen conservador que empleó tanto a la Iglesia como a la religión católica como bases ideológicas de su proyecto político, haciendo difícil, para el siglo XX, pensar en la posibilidad de un Estado laico y de una sociedad secularizada.

\section{Bibliografía}

\section{Fuentes primarias}

\section{Periódicos}

Boletín Noticioso (Bogotá, Colombia), 4 de noviembre 1862.

El Catolicismo (Bogotá, Colombia), 1 de julio 1850-1 de junio 1853.

El Colombiano (Bogotá, Colombia), 23 de noviembre 1861-25 de julio 1862.

El Neogranadino (Bogotá, Colombia), 31 de diciembre 1852-18 de agosto 1853.

Gaceta Oficial (Bogotá, Colombia), 3 de marzo 1855.

La Religión (Bogotá, Colombia), 24 de mayo 1853-7 de julio 1853.

\section{Fuentes secundarias}

Annino, Antonio y François-Xavier Guerra, coords. Inventando la nación. Iberoamérica. Siglo XIX. México: Fondo de Cultura Económica, 2003.

Bastian, Jean-Pierre. Los disidentes: sociedades protestantes y revolución en México, 1872-1911. México: Fondo de Cultura Económica; El Colegio de México, 1989. . La mutación religiosa de América Latina. México: Fondo de Cultura Económica, 1997.

Bazant, Jan. Los bienes de la Iglesia en México (1856-1875): aspectos económicos y sociales de la revolución liberal. 2 ed. México: El Colegio de México, 1977.

. "La Iglesia, el Estado y la sublevación conservadora de Puebla en 1856”. Historia Mexicana (México), 35, núm.1 (julio-septiembre, 1985).

Bushnell, David y Nelly Macaulay. El nacimiento de los países latinoamericanos. Madrid: Nerea, 1989. 
Constituciones de Colombia, recopiladas y precedidas de una breve reseña histórica por Manuel Antonio Pombo y José Joaquín Guerra. 4 t. Bogotá: Ministerio de Educación Nacional, 1951.

Coy Sierra, Andrey Arturo. “Tolerancia religiosa en Bogotá y la revolución liberal de Medio Siglo (1849-1854)”. Monografía de pregrado en Historia, Universidad Nacional de Colombia, Bogotá, 2004.

Cosío Villegas, Daniel. La constitución de 1857 y sus críticos. México: Clío, 1997.

Covo, Jacqueline. Las ideas de la Reforma en México (1855-1861). México: UNAM, 1983.

Díaz Díaz, Fernando. La desamortización de bienes eclesiásticos en Boyacá. Tunja: UPTC, 1977.

. "Estado, Iglesia y desamortización”. En Manual de Historia de Colombia. T. 2. Bogotá: Procultura, 1984.

Díaz, Lilia. "El liberalismo militante”. En Historia general de México. México: El Colegio de México, 1999.

Gómez Álvarez, Cristina. "Mitra y sable se unen para sellar la independencia”. En Relaciones Estado-Iglesia. Encuentros y desencuentros, comp. Patricia Galeana. México: Archivo General de la Nación, 1999.

Hale, Charles. El liberalismo mexicano en la época de Mora, 1821-1853. México: Siglo XXI, 1987.

Hernández Chávez, Alicia. México. Una breve historia. Del mundo indígena al siglo XX. 2 ed. México: Fondo de Cultura Económica, 2002.

Knowlton, Robert. Church Property and the Mexican Reform, 1856-1910. DeKalb: Northern Illinois University Press, 1976.

. "Expropiación de los bienes de la Iglesia en el siglo XIX en México y Colombia: una comparación”. En El siglo XIX en Colombia visto por historiadores norteamericanos, comp. Jesús Antonio Bejarano. Bogotá: La Carreta, 1977.

König, Hans-Joachim. En el camino hacia la nación. Bogotá: Banco de la República, 1993.

Las constituciones de México, 1814-1989. México: Congreso de la Unión, Comité de Asuntos Editoriales, 1989. 
Lynch, John. Caudillos en Hispanoamérica, 1800-1850. Madrid: Mapfre, 1993.

Mejía Velilla, David. Glosas a la desamortización y otras páginas de historia. Bogotá: Universidad de La Sabana, 1998.

Munguía, Clemente de Jesús. En defensa de la soberanía, derechos y libertades de la Iglesia. 2 ed. 1857; reimpresión, México: Editorial Tradición, 1973.

Rabasa, Emilio. La Constitución y la dictadura. Estudio sobre la organización política de México. 3 ed. México: Porrúa, 1956.

Restrepo Piedrahíta, Carlos. Constitución política de la primera república liberal 1853-1856. Bogotá: Universidad Externado de Colombia, 1979.

Restrepo, Juan Pablo. La Iglesia y el Estado en Colombia. Londres, 1885; reimpresión, Bogotá: Banco Popular, 1985.

Rivera Reynaldos, Lisette Griselda. Desamortización y nacionalización de bienes civiles y eclesiásticos en Morelia, 1856-1876. Morelia: Universidad Michoacana de San Nicolás de Hidalgo, 1996.

Sinkin, Richard. The Mexican Reform, 1855-1876. A study in Liberal NationBuilding. Austin: The University of Texas at Austin, 1979.

Tirado Mejía, Álvaro. “Estado y política en el siglo XIX”. En Manual de Historia de Colombia. T. 2. Bogotá: Procultura, 1983.

Villegas Revueltas, Silvestre. El liberalismo moderado en México, 1852-1864. México: Universidad Nacional Autónoma de México, 1997.

Villegas, Jorge. Colombia. Enfrentamiento Iglesia-Estado, 1819-1887. Bogotá: La Carreta, 1981.

Zarco, Francisco. Crónica del Congreso Constituyente. México: El Colegio de México, 1957. . Historia del Congreso Extraordinario Constituyente de 1856 y 1857. 2 t. México: Congreso de la Unión, 1990.

. Debate en el Congreso Constituyente, 1856-1857. México: Centro de Investigación Científica Ing. Jorge L. Tamayo, 1991. 